
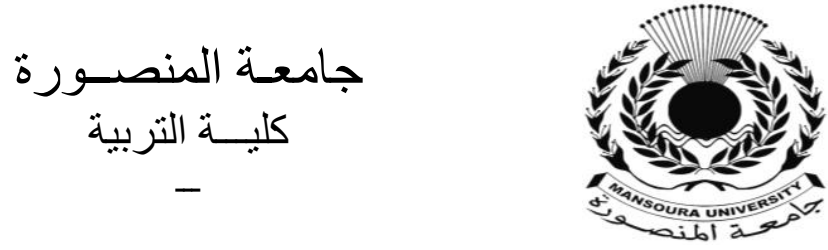

\title{
تصميم بيئة تعليمية الكترونية قائمة على الفصل \\ المعكوس لتنمية تصصيل القواعد النحوية لدى طلاب \\ المرحلة الثانوية بجمهورية العراق
}

\author{
إعداد \\ الباحث / مهند خالد جاسم الخليفاوي \\ إشر افت \\ أ.م.د/منال شوقي بدوي \\ أستاذ تكنولوجيا التعليم المساعدي \\ كلية التربية - جامعة المنصورة

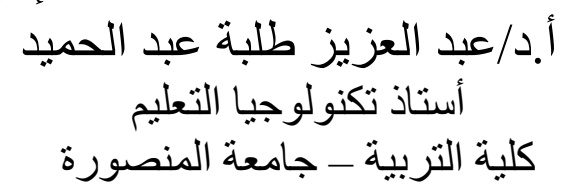 \\ أ.د/عبد العزيز طلبة عبد الحمبد \\ أستاذ تكنولوجيا التعليم \\ كلية التربية - جامعة المنصورة
}

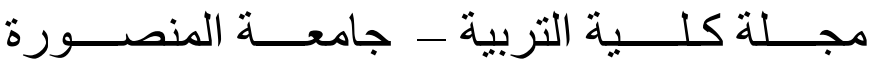

$$
\begin{aligned}
& \text { العدد 111 }
\end{aligned}
$$


تصميم بيئة تعليمية الكترونية قائمة على الفصل المعكوس لتنمية تحصيل

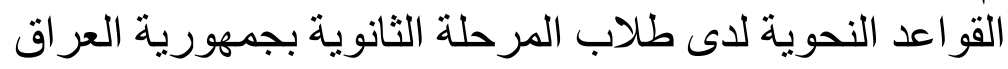

\section{مهند خالد جاسم الخليفاوي}

المقدمة

يشهد العصر الحالي طفرة هائلة في ظهور المستحدثات التكنولوجية التعليمية، لذلك

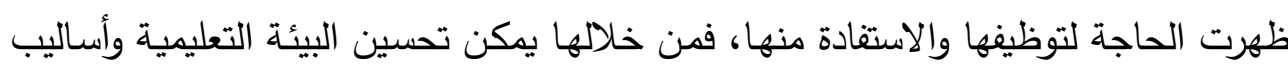

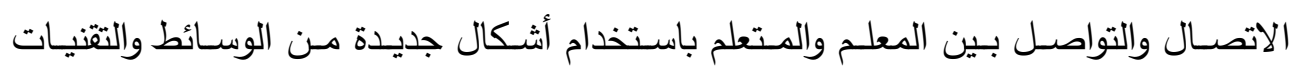

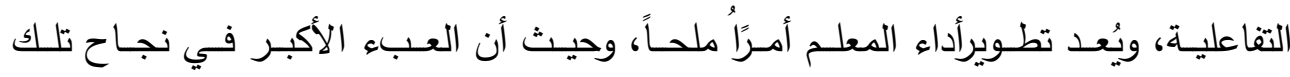

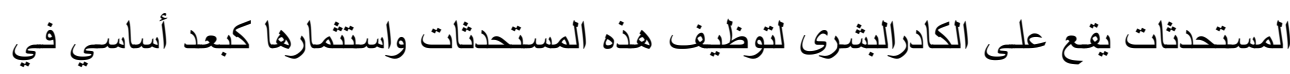

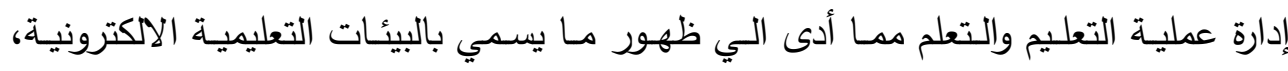
والفصل المعكوس.

ويشير (Parker\& Martin, 2020, 136 ) أن البيئات الالكترونية تتيح التواصل

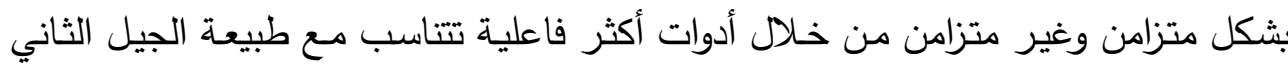

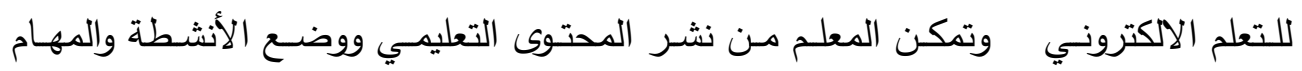

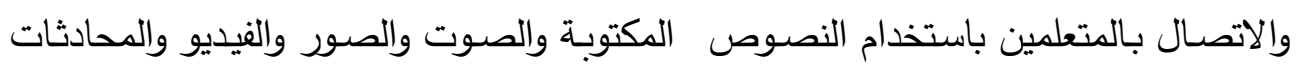

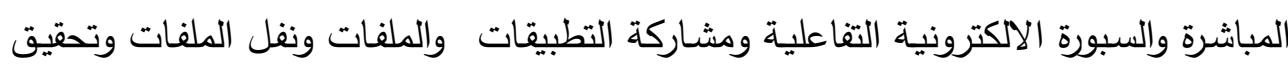
المشاركة الفعالة من جانب المتعلمين في ساحات النقاش والحوار .

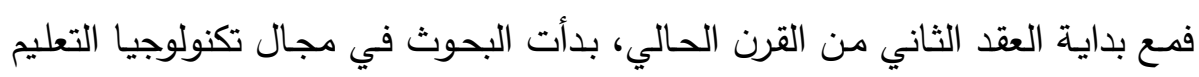

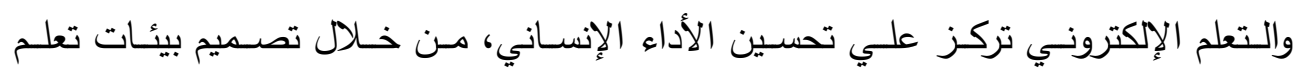

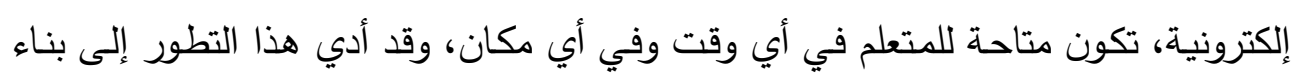

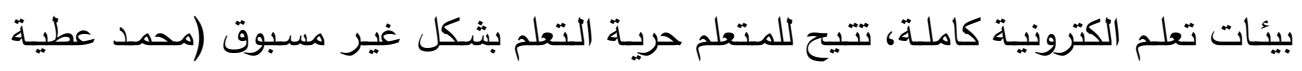

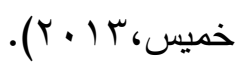
وهناك العديد من الدراسات التي ذكرت أنَّ بيئات التعلم الآكترونية هي أحد أساليب

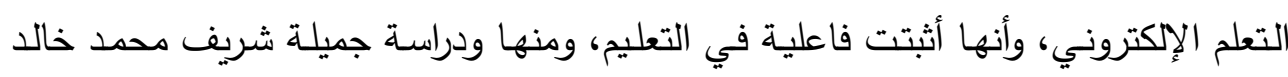




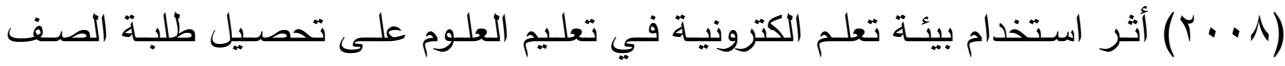

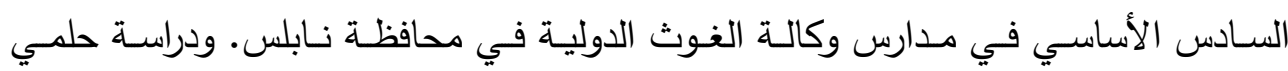

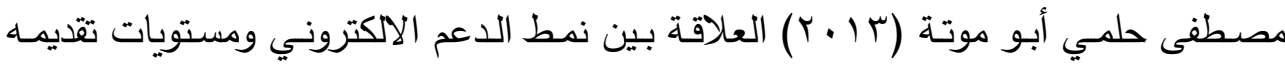
عبر بيئات التعلم الالكترونية في تتميـة التحصيل والتتكير الابتكاري، ودراسـة منى هـادي

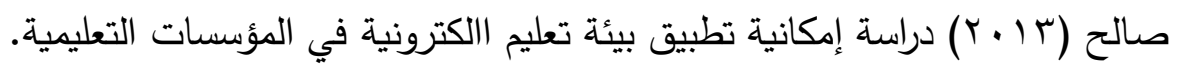

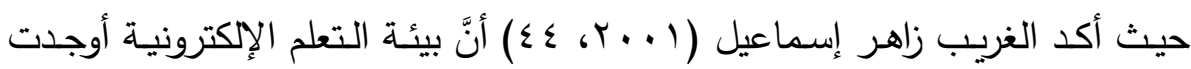
الفعالية في تعليم الطلاب من خلال تصميم وتمثيل معلومات ثلاثية الابعاد كبرامج متعددة الوسائل مما يساعدهم على بناء خبرات تعليميه فعاله. وأوضـح اتكنسون، (Atkinson, 2005) التأثيرات الفعالة للتكنولوجيا واستخدام بيئات التعليم الالكترونية في تطوير العلاقات التعاونية بين المعلمين بعضهم البعض، وأيضاً بين المتعلمين، حيث تعمل تلك البيئات على تزويد المعلمين بالتدعيم والتعاون من أجل التعليم

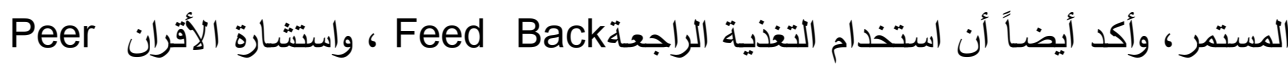
مـن خـلال بيئـات التعلم الإكترونيـة ذات علاقـة ايجابيـة لاستخدام المعلم لتلك البيئات في العملية التعليمة، وبالتالي تعمل تلك البيئات على زيادة التفاعل بين مجموعات الأقران من المعلمين والمتعلمين. ومن المزايا أيضـا التي تقدمها البيئات التعليمية للمتعلمين، القدرة على الدخول إلى المقررات الدراسية لأي مؤسسة من خارج حدود هذه المؤسسة، سواء للطـلاب الذين يؤدون واجبهم المنزلي، أو غير القادرين على الحضور للمؤسسة التعليمية.

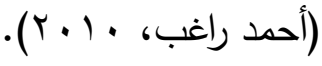

كمـا اكدت الكثير من المؤتمرات على أهميـة توظيف بيئات التعلم الالكترونيـة في التغلب على مشكلات التعلم كذلك ضـرورة إعداد معلمي المدارس الثانويـة بما يتماشى مـع متغيرات العصر ومنها: - n توصيات المؤتمر الخامس لإعداد المعلم تحت عنوان إعداد وتدريب المعلم في ضوء

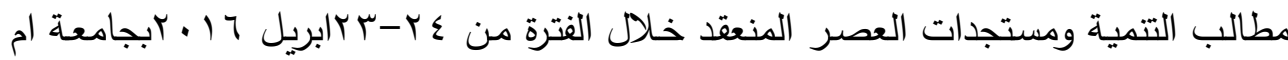
القـري بالمملكـة العربيـة السـعودية، والـذي اوصـي بضـرورة إعـداد المعلـم وفـق متغيـرات 
ومستجدات العصـر والتطورات التكنولوجيـة وتدريبة على كيفيـة استخدام التقنيـة وتوظيفها داخل المؤسسة التعليمية.

وتوصيات المؤتمر الدولي المعلم وعصر المعرفة: الفرص والتحديات تحت شعار (معلم متجدد لعالم متغير) المنعقد خلال الفترة من • ب-9 بنوفمبر 7 ا • بابجامعة الملك خالد

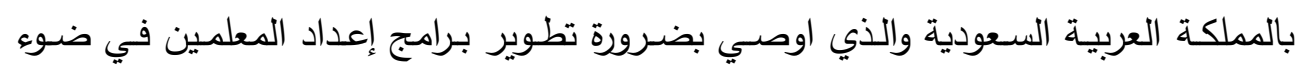
متطلبات عصر المعرفة.

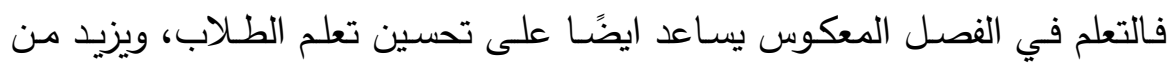

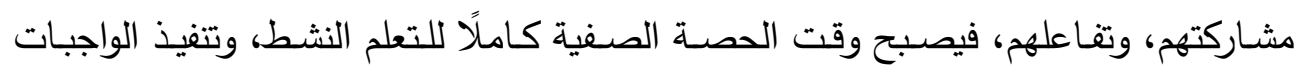
والدروس، لذلك فكرة التعلم بالفصل المعكوس تستتد في أسـاس تكوينها إلى مفـاهيم مثل ولت (التعلم النشط، وتصميم مختلط للدرس، وفاعلية الطلاب ومشاركتهم) (حنان بنت اسعد الزين

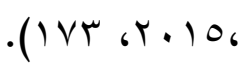

ومن ضمن الأسـاليب التي يمكن أن يستخدمها المعلم في تدريس النحو هو أسلوب

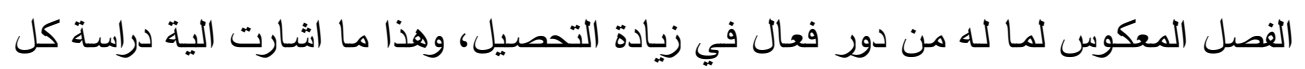

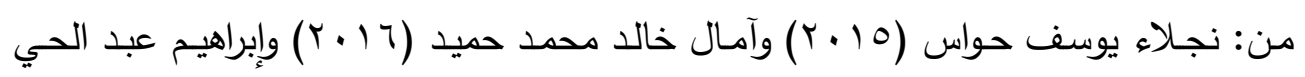

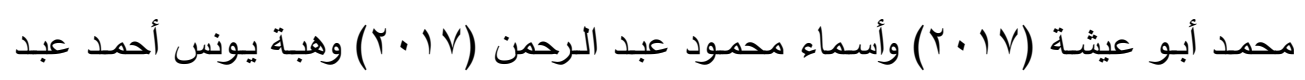

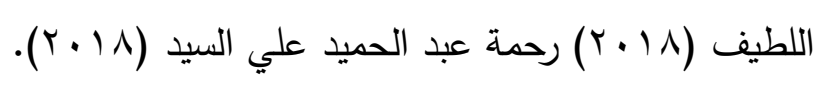
وتأسيسًا على ما تقدم، يرى الباحث أن استخدام التقنية الحديثة في تعليم اللغة العربية

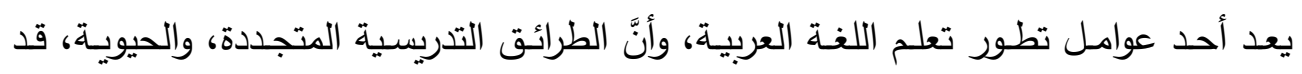

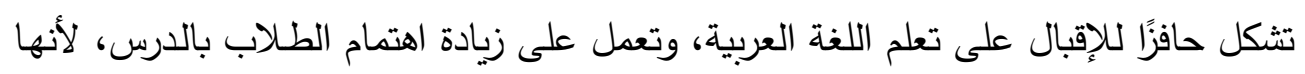

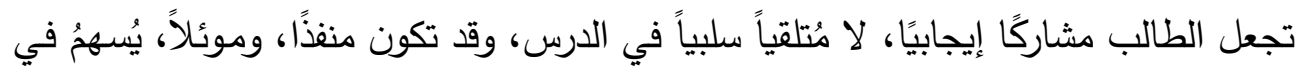

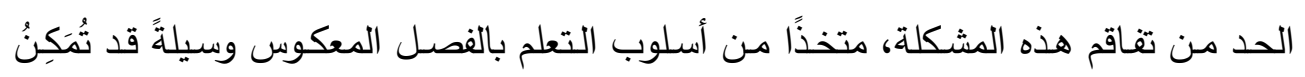
الطلبة من تنمية تحصيل القواعد النحوية. ومن هنا ظهرت الحاجة إلى البحث، إذ إن إتباع المدرس طرائق تدريسية حديثة تتسم

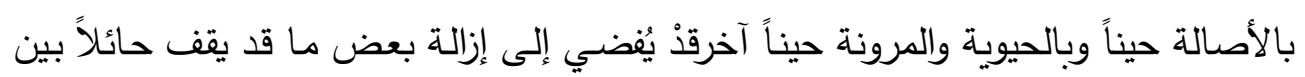
اللغة والطلبة من ضعفٍ وقصورٍ وجفاء. 


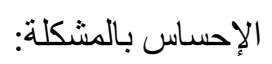

في ضـوء مـا تقدم تبين فاعلية بيئات التعلم الافتراضية وأهمية التفاعل كأحد أبرز العناصـر المؤثرة في كفـاءة الفصـل المعكوس، كمـا اتضـح أن هنـاك قصـورًا في تحصيل المفاهيم النحوية وضعفًا في توظيف التكنولوجيا في تدريس اللغة العربية. وقد لمس الباحث

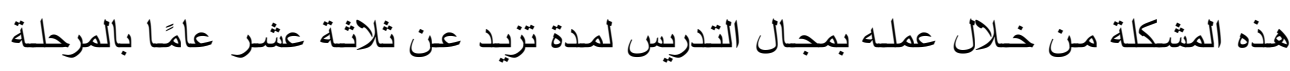

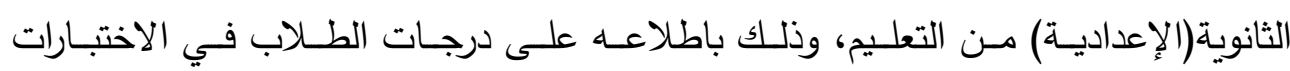

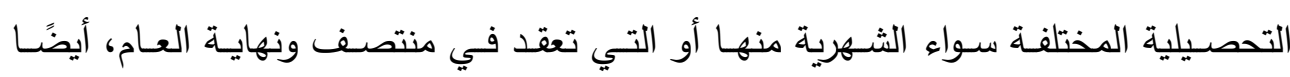
اتضحت المشكلة من خلال كتابات الطلاب في مادة الإنشاء(التعبير التحريري)، حيث وجد

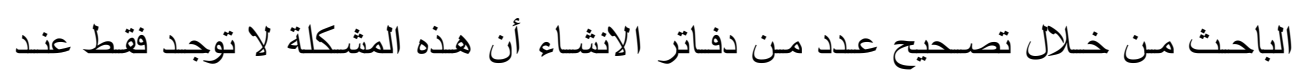
منخفضي التحصيل، ولكن توجد أيضًا عند الطلاب مرتفعي التحصيل، الذين يقعون في الكثير من الأخطاء النحوية عند الكتابة.

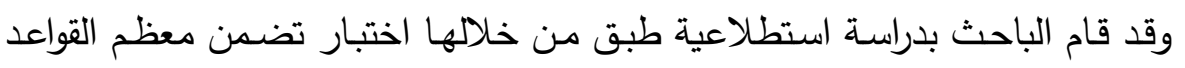
النحوية التي درَسَها طلاب الصف الخامس الثانوي (الفرع العلمي) في السنوات السابقة (أي في الصف الرابع والثالث). وقد أظهرت نتائج الدراسة الاستطلاعية أن نسبة من أخطأ في

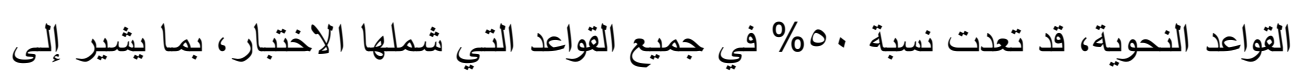
وجود ضعف في هذه القواعد لدى طلبة الصف الخامس الثانوي (الفرع العلمي)، وقد يرجع هذا الضعف إلى عوامل عدة منها، ما يتعلق بطبيعة القواعد النحوية، وجمودها، وبعدها عن

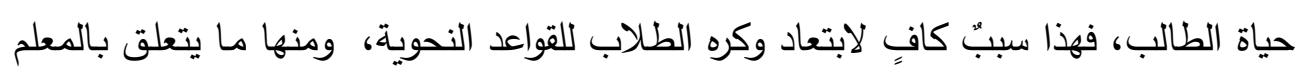

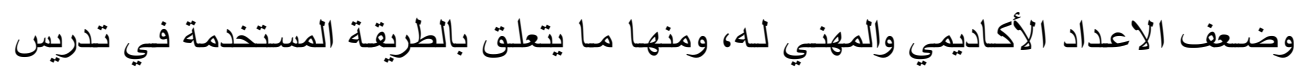
النحو، التي قد لا تكون مناسبة ومشوقة للطـلاب، ومنها الطالب نفسـه وخوفـه مـن النحو

تحديد مشكلة البحث: ورغنه

تتحدد مشكلة البحث فيما يعاني منه طلاب الصف الخامس الثانوي (الفرع العلمي) من ضعف في تتمية تحصيل القواعد النحويـة، ومن ثََّّ عزوفهم عن النحو وتكوين اتجاهات سلبية نحوه، وللتصدي لهذه المشكلة يحاول البحث الإجابة عن السؤال الرئيس التالي: 
ما فاعلية بيئة تعليمية الكترونية قائمة على الفصل المعكوس لتنمية تحصيل القواعد النحوية لاى طلاب المرحلة الثانوية بجمهورية العرلق؟ لتوبه ويتفرع من هذا السؤال الرئيس الأسئلة التالية: ا ـ مـا معايير التصـيم التعليمـي الواجب توافرهـا في البيئة التعليميـة الاككترونيـة القائمـة

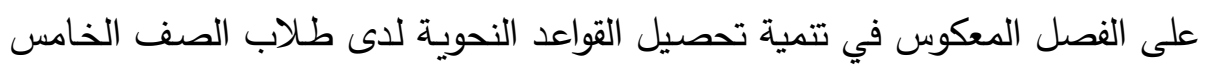
الثانوي بجمهورية العراق؟ r. ما القواعد النحويـة المتضمنة في منهج اللغة العربية لطلاب الصف الخامس الثانوي الفرع العلمي بجمهورية العراق؟ ماع r. ما التصميم التعليمي للبيئة التعليمية الأكترونية القائمة على الفصل المعكوس لتتمية تحصيل القواعد النحوية لدى طلاب الصف الخامس الثانوي بجمهورية العراق؟ ء. مـا البيئة التعليميـة الأكترونيـة القائمسة على الفصل المعكوس لتتميـة تحصيل القواعد النحوية لاى طلاب الصف الخامس الثانوي بجمهورية العراق؟ ه. مـا فاعلية البيئة التعليميـة القائمسة على الفصل المعكوس في تتميـة تحصيل القواعد النحوية لدى طلاب الصف الخامس الثانوي بجمهورية العراق؟ أهداف البحث:

هدف البحث الحـالي إلى تتميـة تحصيل القواعد النحويـة مـن خـلال توظيف البيئة

$$
\begin{aligned}
& \text { التعلميمية القائمة على الفصل المعكوس في المدارس الثانوية. } \\
& \text { أهمية البحث: يمكن أن يسهم البحث الحالي فيما يلي: }
\end{aligned}
$$

ا ـ توصـيل المحتوى التعليمسي للطـلاب، وتطـوير قدراتهم، ومهـاراتهم مـن خـلال البيئة التعليمية الالكترونية القائمة على الفصل المعكوس. r. توفر البيئة التعليمية الاكترونية فرص التعلم المختلفة وتوفر محتوى تعليمى إلكترونى يساعدة الطلاب على الارتقاء بمستواهم العلمي والتقني.

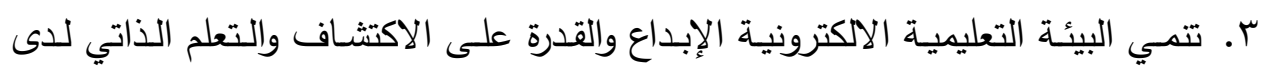
الطلاب. 
ع. الوصـول لقائمـة بالمعـايير التصـميمية لبيئـة تعليميـة قائمــة على الفصـل المعكـوس لتحصيل القواعد النحوية لدى طلاب الصف الخامس الثانوي.

$$
\text { حدود البحث: اقتصر البحث الحالي على ما يلي: }
$$

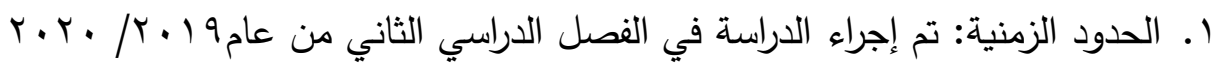

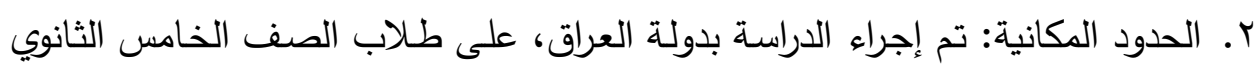
في اعدادية غرناطة للبنين في محافظة الأنبار • r. الحدود الموضـوعية: اقتصـر البحث الحـالي على بعض مفـاهيم كتاب قواعد اللغــة العربية، ويشمل (التوابع في اللغة العربية، ومنها: النعت، والعطف، والبدل)، بالإضـافة

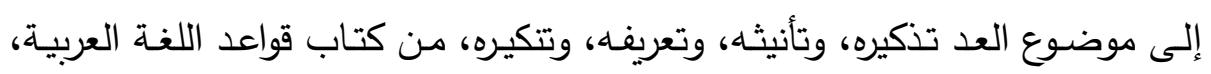

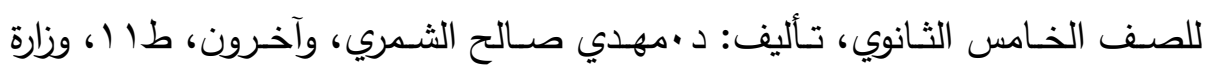
التربية، العراق، بغداد، 1 1 ـ ب، وهو الكتاب المعتمد لدى وزارة التربية العراقية.

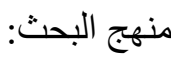
يستخدم الباحث المنهج شبه التجريبي في تصديم وإنتاج بيئة التعليمية الاككترونيـة القائمة على الفصل المعكوس، وقياس فعاليتها وكفاءتها ويتضمن:

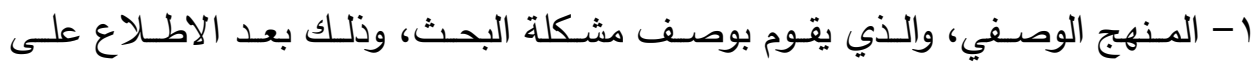
الدراسات والأدبيات السابقة، العربية منها والأجنبية المشابهة لموضوع البحث الحالي. r- المنهج شبه التجريبي، لقياس أثر المتغيرالمستقل (تصميم بيئة تعليمية الكترونية قائمة

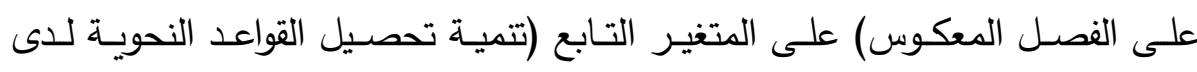
طلاب الصف الخامس الثانوي.

التصــميم التجريبـي: يعتمــ البحـث الحـالي على التصـميم التجريبـي القـائم على المجمـوعتين التجريبيتين، حيـث يتم اختيـار عينـة عشـوائية، يتم تقسيمها إلى مجمـوعتين

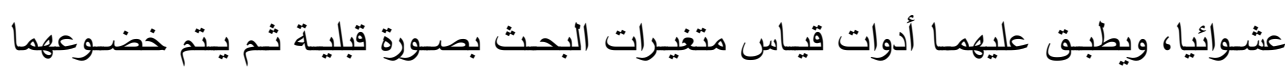
للمعالجة التجريبية ثم يطبق عليهما أدوات قياس متغيرات البحث بصورة بعدية. فروض البحث: 1- يوجد فرق دال إحصائيًا عند مستوى (0. . • ) بين متوسطي درجات طلاب المجموعة التجريبية الأولى، والمجموعة التجريبية الثانية في التطبيق البعدي للاختبار التحصيلي 
الخاص بتتمية تحصيل القواعد النحوية (الخامس الثانوي) لصالح المجموعة التجريبية

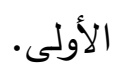

ץ- يوجد فرق دال إحصائيًا عند مستوى (0 ., ·) بين متوسطي درجات طلاب المجموعة

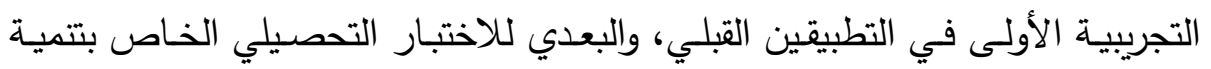
تحصيل القواعد النحوية (الخامس الثانوي) لصالح التطبيق البعدي.

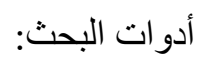

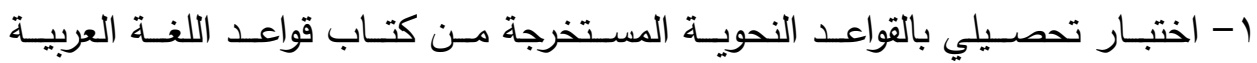

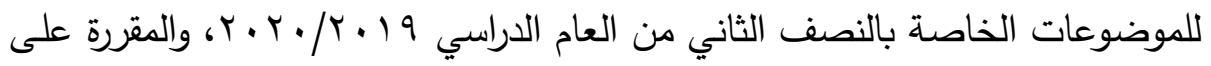

$$
\text { تتحدير متغيرات البحث: }
$$

1. المتغير المستقل: تصميم بيئة تعليمية الكترونية قائمة على الفصل المعكوس).

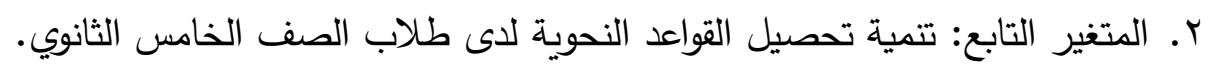

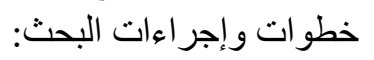
1- الاطلاع على الأدبيات والبحوث المرتبطة بالبيئات التعليمية الاككترونية القائمة على التى الفصل المعكوس لتتمية تحصيل القواعد النحوية (الخامس الثانوي) r- إعداد قائمة بمعايير تصميم البيئة التعليمية الالكترونية القائمة على الفصل المعكوس الفئس

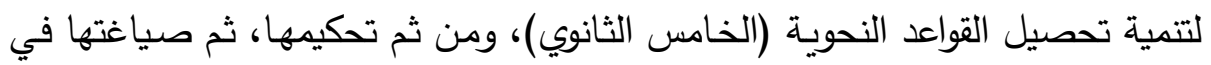
صورتها النهائية. r- إعداد قائمة بالأهداف الإجرائية الخاصـة بالوحدات التعليميـة لتتمية تحصيل القواعد

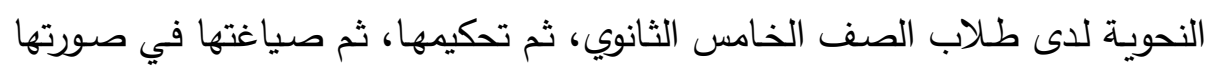
النهائية. ع - إعداد سيناريو تصميم البيئة التعليمية الالكترونية القائمة على الفصل المعكوس لتتمية تحصيل القواعد النحوية (الخامس الثانوي)، وتحكيمه، وصياغته في الصورة النهائية النهائية. 0- تصميم وبناء البيئة التعليمية الالكترونية القائمة على الفصل المعكوس لتتمية تحصيل القواعد النحوية (الخامس الثانوي). 


$$
\text { 7- إعداد أدوات القياس، وهي: }
$$

أ. اختبار تحصيلي معرفي لتنمية تحصيل القواعد النحوية الخاصة بطلاب الصف وهف

$$
\text { الخامس الثانوي. }
$$

V- عرض أدوات القياس على مجموعة من المحكمين في مجال التخصص لتتأكد من

$$
\text { صدقها وصلاحيتها للتطبيق. }
$$

^- حساب ثبات أدوات القياس المختلفة من خلال التجريب الاستطلاعي، وذلك بعرضها

$$
\text { على عينة من طلاب الصف الخامس الثانوي. }
$$

9- تطبيق أدوات القياس القبلي على الطلاب عينة الدراسة ( • ؟).

• 1- استخدام البيئة التعليمية الاككترونيـة المقترحة على المجموعتين التجريبيتين ( • ال) طالبًا.

$$
\text { 11 - تطبيق أدوات القياس البعدي على أفراد العينة (• (7) طالبًا. }
$$

r ا - تسجيل نتائج القياس القبلي والبعدي لأدوات القياس، وإجراء المعالجـة الإحصـائية

$$
\text { عليهما، ثم تفسير النتائج ومناقتشتها. }
$$

$$
\text { سا - تتديم التوصيات والمقترحات في ضوء نتائج البحث. }
$$

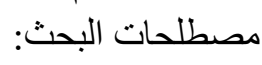

بيئة التعلم الالكترونـي: هي منظومـة متكاملة ومتفاعلة ومرنـة تعتمد على شبكات الإنترنت، وتوظف فيها أدوات الاتصـال الإلكترونيـة بنمطيه المتزامن وغير المتزامن لتقديم محتوى قواعد اللغـة العربية بثكل إلكتروني لطلاب الصف الخامس الثانوي عن طريق الفصل المعكوس لتتمية التحصيل لديهر.

الفصل المعكوس: هو بيئة تعليمية تقدم نوعية تعليم وتعلم تتاسب خصـائص طلاب

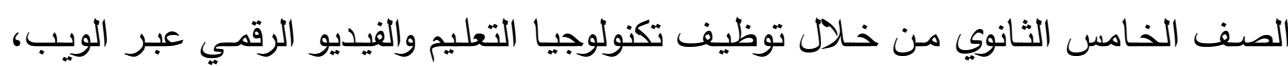

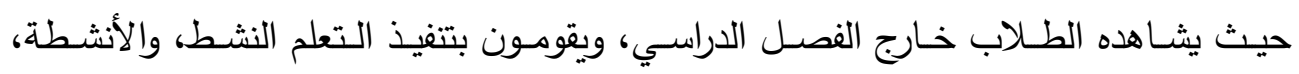
والتدرببات داخل الفصل الدراسي التقليدي. 
التحصيل:هو النتيجة التي يحققها طالب الصف الخامس الثانوي في مادة قواعد اللغة العربية (القواعد النحوية) ويقاس بالعلامة التي سيحصل عليها في الاختبار القبلي والبعدي، الذي أعده الباحث لغرض البحث. البه.

القواعد النحوية: هي مجموعة من المفاهيم النحويـة المستنبطة من كتاب قواعد اللغة

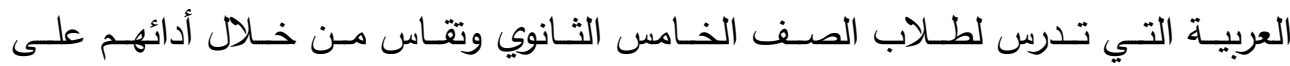
اختبارالقواعد النحوية المعد. الإطار النظري للبحث

تم تقسيم الإطار النظري للبحث المى المحاور الآتية: المحور الأول: بيئات التعلم الالكتروني

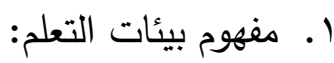

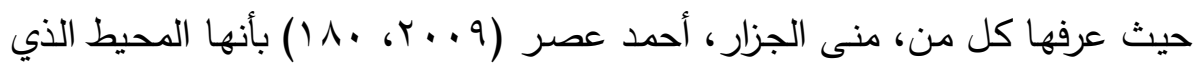
تتم فيه عمليتي التعليم والتعلم، بما يثمله من عوامل ومؤثرات يتوقف عليها مدى جودة مخرجات التعلم وتتجاوز البيئة حدود المكان، والتجهيزات، والموقع إلى العلاقات الإنسانية وأسلوب التواصل وغيرها من العوامل.

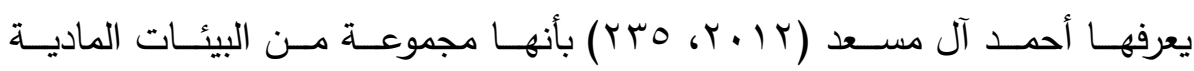
والافتراضية والاجتماعية والتي تسهل التفاعل والخصوصية الفردية في عمليات التعلم.

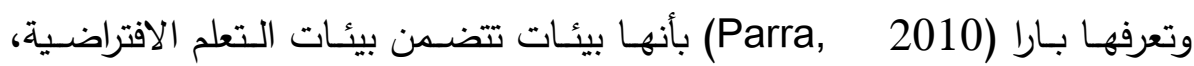
والمقـررات الالكترونيـة، والفصـول الاككترونيـة، ومجموعـات العمـل الالكترونيـة كجـزه مـن الأنظمة الاككترونية، ويتم احداث هذه البيئات من خلال أنظمة التعلم الالكتروني. r. مميزات استخدام بيئات التعلم الإلكترونية في التعليم.

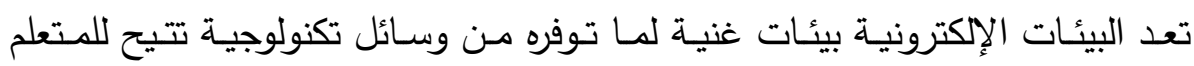
إمكانية تلقي المعلومات بأقل جهد، وتتيح لـه الحوار والتفاعل بينه وبين زملاءه ومـع معلميه لإسـتكمال العمليـة التعليميـة، وتسـهل تقديم التغذيـه الراجعـة، وتـوفر للمعلم إمكانيـة تقديم المسـاعدة والتواصل مـع المتعمين وتطوير استراتيجيات التدريس التي يتبعها، وبذلك فإن

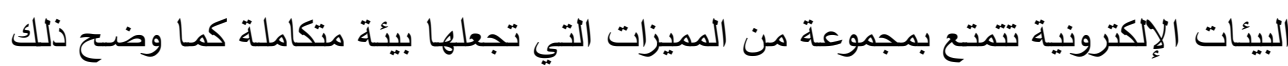




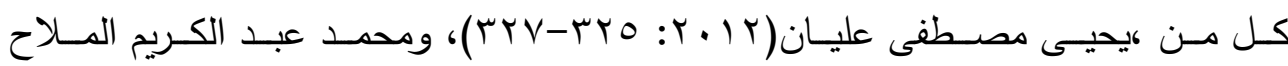

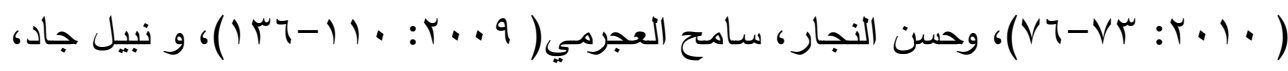

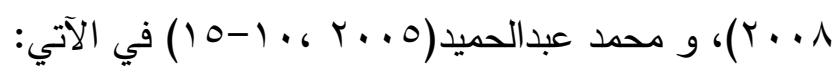

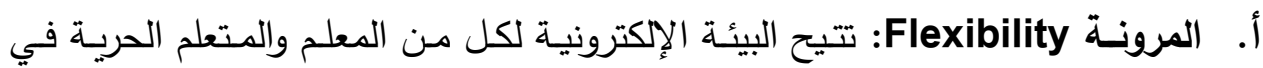

إختيار الوقت المناسب لهج، وإختيار طرق التواصل والمشاركة فيما بينهم، والتنوع في مصادر المعلومات لإثراء خبرات المتعلمين، وأيضـاً التتوع في أساليب التغذية الراجعة feed back ب. الفاعليـة Effectiveness: تزيد البيئة الإككترونيـة مـن فاعلية إستيعاب المتعلمين

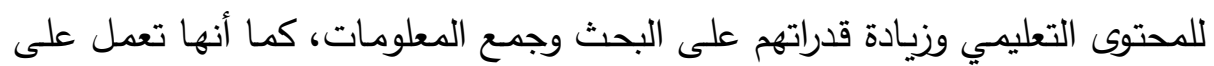
زيـادة التواصـل بين المتعلمين لتدعيم مـا لديهم مـن مهارات الإتصـال الإجتمـاعي، وفئ وتعمل على إستتارة إهتمـام المتعمين بتتوع المعـارف والخبـرات التي تقدمها البيئة ليختار منها المتعلم ما يناسب إهتماماته. ج. المســاواة Equity: تـوفر البيئـة الإلكترونيـة مبـدأ المسـاواة في تقـديمها للخدمات التعليمية للمتعلمين، حيث أنها تراعي الفروق الفردية بينهم دون الإنحياز لأحد بعينه، وكما تتيح تكرار التعلم وتوافر المنهاج في أي وقت ومن ثم سـولة توصيل المواد الدراسية والمعلومات بسرعة ودقة للوصسول إلى الإتقان، والتغلب على أعباء الإدارة التقليدية. د. الملائمـة Convenience: تـوفر البيئـات الإككترونيـة الظروف المناسبة لكل مـن المعلم والمتعلم حيث تعمل على: إيصال المعلومات للمتعلمين دون التقييد بالزمان أو لئه المكان، وإستخدام أسـاليب ووسائل متتوعة لتوصيل المعلومات، وجعل المتعلم محور العملية التعليمية وإعطاءه حرية التعبير عن آراءه وأفكاره. هـ تــوع الحـواس Multi-sensory: يختلف كل متعلم عن الآخر وهذا يتطلب أن تكون البيئة الإكترونية بيئة غنية توفر مصادر تعلم متتوعة لتدعيم المحتوى، ووسائل إضافية معينة (صور ، فيديو، رسوم توضيحية...). 
وأضـاف ( . (Sandy B. Oleg L, 2000) بأنه توجد مميزات عديدة لاستخدام بيئات التعلم الإلكترونية في التعليم منها: التوافق مع زيادة أعداد المتعلمين، والمشاركة وإعادة استخدام الموارد والمرونـة في الاستخدام، والعمل التعاوني والمناقثـة التي تؤدي إلى التعلم التعاوني، والتعليم المتمركز حول المتعلم، وتخفف أعباء الإدارة التقليدية.

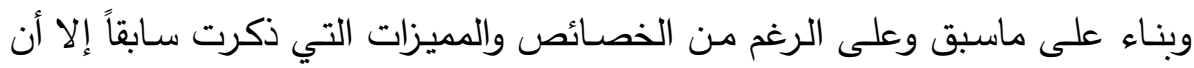
عملية توظيف البيئات التعليمية الإلكترونية في العملية التعليمية قد تواجهه العديد من من فئ الصعوبات والتي يأتي في مقدمتها القصور في تصميم البيئات التعليمية الإلكترونية، وعدم القدرة على إختيار الإستراتيجيات التعليمية المناسبة التي توفر أفضل استخدام لمصـادر

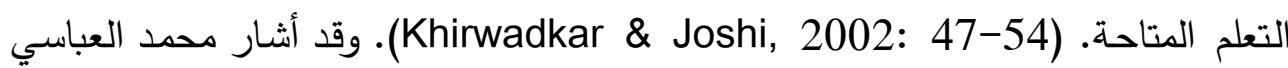

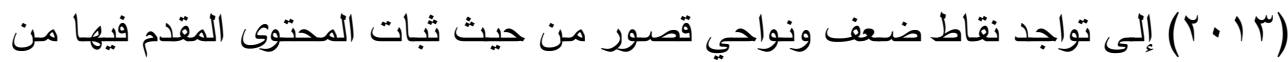
قبل المعلم، وعدم توافر الخصوصية للمتعلم أثناء مراحل تعلمه، كما أن أدوات الإتصـال فيها عامـة، وثبات التقويم والأنشطة، ولا تتيح البيئة بصفة أساسية للمتعلم أن يساهم في إنتاج المحتوى وفق قدراته واحتياجاته المعرفية. ب. أهمية استخدام البيئات الإلكترونية: ترجع أهمية استخدام البيئات الإككترونية إلى العديد من الأسباب الناتجة عن توظيفة المستجدات التكنولوجية في العملية التعليمية، حيث ساهم استخدام وتوظيف تكنولوجيا التعليم والتعلم الإلكترونـي في جعل البيئـات الإلكترونيـة ذات فاعليـة كبيـرة في تقديم المعلومـات للمتعلمين بمـا يتتاسب وقدراتهم وإتاحسة الوسـائل والأدوات التي تسهل عليهم عمليـة التعلم وتجعل المتعلم أكثر تفاعلاً وإيجابية وقد أشار كل من، أحمد ماضي (10 ب ب)، إبراهيم عبد

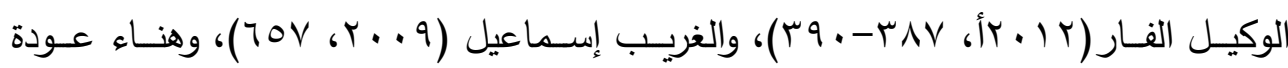
خضري (^ . . r) إلى أن أهمية استخدام البيئات الإلكترونية ترجع إلى الأسباب التالية: ا ـ إتفاقها مع المبدأ التربوي في تغير دور الطالب وجعله محور العملية التعليمية. r. تلبيتها لمتطلبات العملية التعليمية وعناصرها. r. تطبيق النظام التعليمي وإدارته وتطويره وتقييمه. ء. تتظيم ومراقبة العملية التعليمية لكل من المتعلمين والمعلمين. 
ه. تقديم المساعدة والدعم عن طريق تحديد أهداف التعلم الخاصة بهم. 7. إدارة المحتوى والعملية التعليمية على حد سواء. V. تحقيق جودة التعلم، وتخفيض وقت وجهد وتكاليف العملية التعليمية، وإنسجامها مـع التغيرات التي حدثت على الطرق التربويــة والتي ركزت على أنظمـة التعليم والتعلم الإلكتروني.

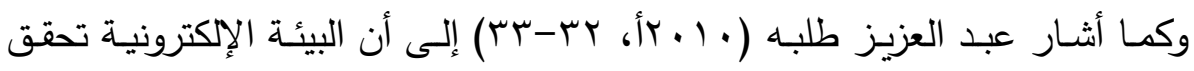

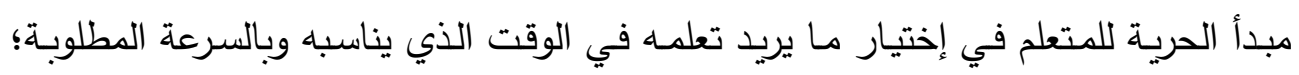
حيث تمكنه من تخطى المستويات التعليمية التي يراها غير مناسبة لمستواه، وتوفر لله كم هائل من المعلومات ومن مصادرها الإلكترونية. ولقد تتاولت العديد من الدراسات أهية استخدام وتوظيف البيئات الإلكترونية في تقديم المحتوى التعليمي، مثل: دراسة (carter \& Lange, 2005) والتي أبرزت أهمية استخدام البيئات الإلكترونية لما لها من مهام تعمل على تحديث المعلومات والمناهج المتاحة

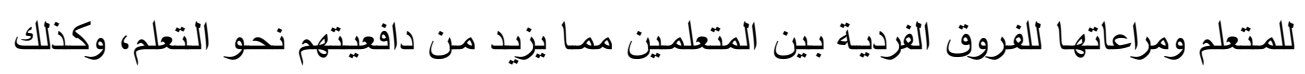

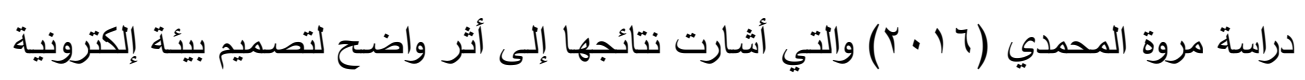

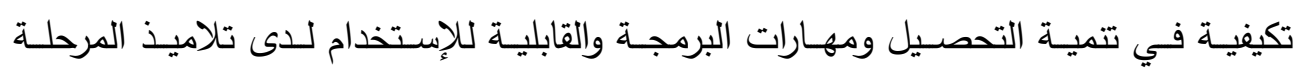
الإعدادية. وقد أكدت دراسة جمال مصطفى الثرقاوي(؟ . . ب)على فاعلية استخدام بيئة التعلم الإلكتروني في تدريس المقررات التي تحتوي على مهارات عملية مثل مقرر تكنولوجيا

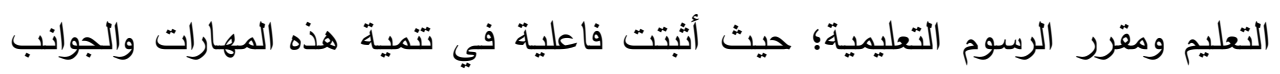
المعرفية المرتبطة بها وجعل التعلم أكثر تعاوناً لما توفره من مصسادر معلومات متعدده،

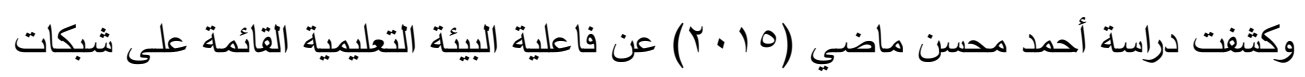

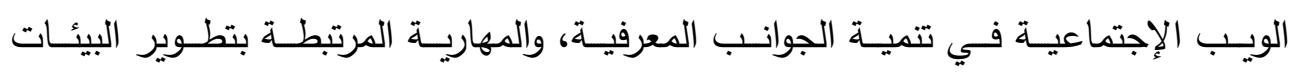
الإلكترونية، كما كان لها أثر في تتمية مهارات التعلم الذاتي الإلكتروني لدى طلاب شعبة تكتولوجيا التعليم. المحور الثاني: الفصل المعكوس وتعلم القواعد النحوية:

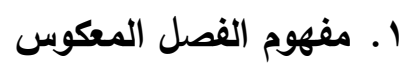


إن مفهوم الفصل المعكوس هو مفهوم حديث وعصري للتعلم كنمط من أنماط التعلم

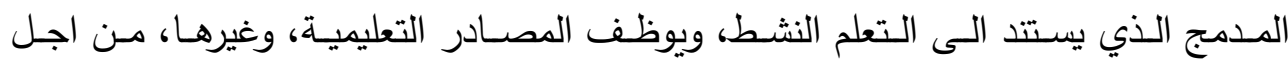
استغلال فترات اللقاء في الصف التقليدي لأنشطة أكثر فاعلية، وأنَّ فكرته ببساطة، تعتمد وغيرة

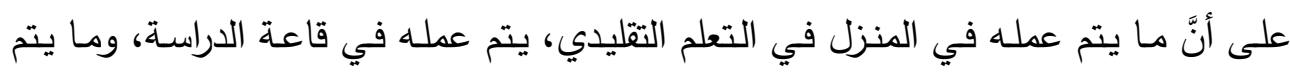

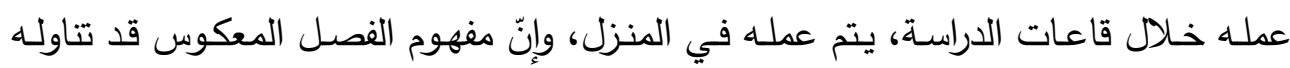
عدد من الباحثين بوجهات نظر مختلفة، وبنائهم للمفهوم بما يتفق مـع رؤيتهم لـه، ومن هذه التعريفات ما يأتي:

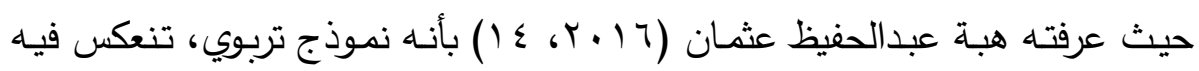

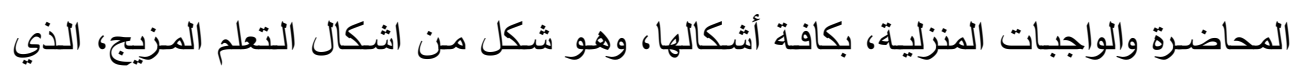
يشمل استخدام التكنولوجية للاستفادة من التعلم في الفصول الدراسية.

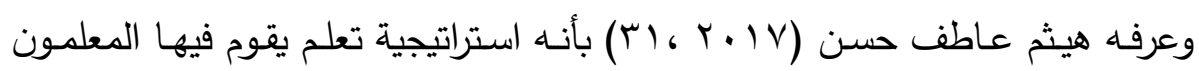
بمساعدة المتعمين على التحضير المسبق للدرس من خلال نشر مقاطي فيديو على إحدى

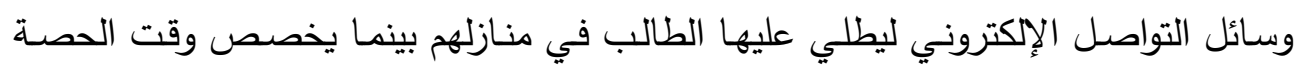
للمناقثات وورش العمل التدريبية.

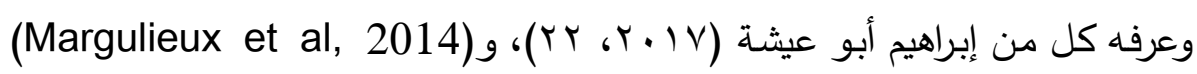
بأنـه نموذج من نماذج التعلم المدمج، تقلب فيه الإجراءات التعليمية، بحيث يتلقى الطلاب

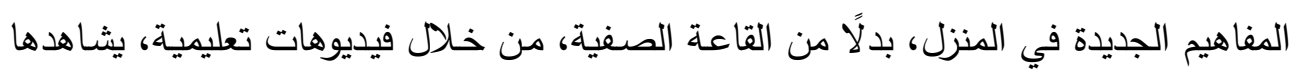
الطالب، من خـلد تقنيات حديثة، مثل الهواتف الذكية والحواسيب وبإشراف المعلم وجها لهن

r. أ. مميزات الفصل المعكوس.

تمتـاز بيئـة الفصـل المعكوس بأنها تخلق فرصــاً فرديـة للتعلم، وقد حـد كـل مـن

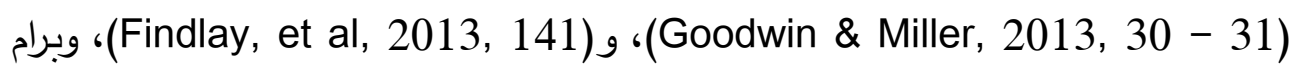

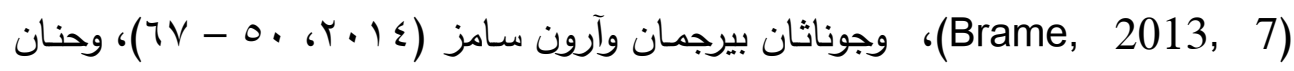

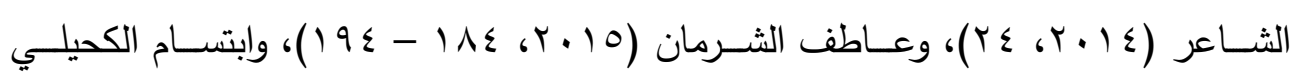




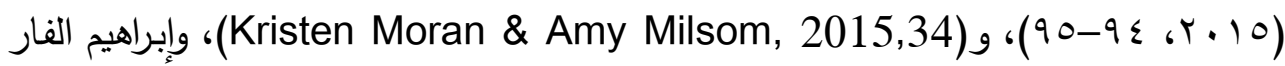

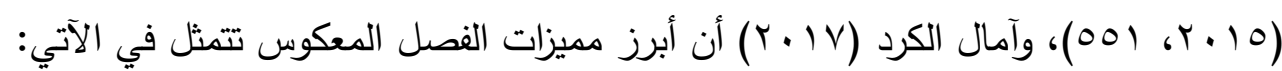
ا ـ. مراعاة الفروق الفردية ومساعدة الطلاب المتعثرين أكاديمياً: r. r. التماشي مع متطلبات ومعطيات العصر الرقمي: r. آ. مساعدة الطلاب ذوي الحاجات الخاصة على التفوق: ع. بيئة تعليمية تحفز مشاركة الطلاب في تبادل المعلومات بينهم: 0. زيادة التفاعل بين المعلم والطالب:

ومن خلال استعراض بعض من مميزات الفصل المعكوس، يرى الباحث أن التعلم من خلال الفصل المعكوس يحقق الاستغلال الأمثل للوقت من قبل المعلم والطالب، حيث

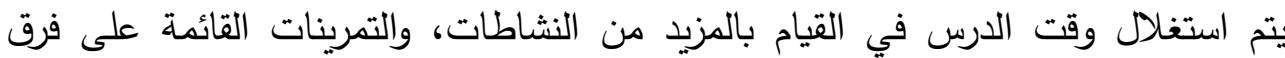

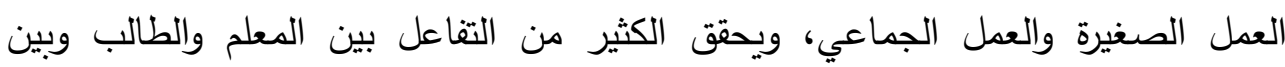
الطلاب أنفههم، ويراعي الفروق الفردية بين الطلاب، من خلال السماح لكل طالب بالتعلم حسب قدرته وسرعته، وإنّ التعلم بالفصل المعكوس يعزز ثقة الطالب بنفسه ويشعره

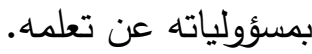

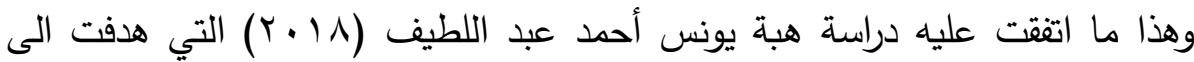

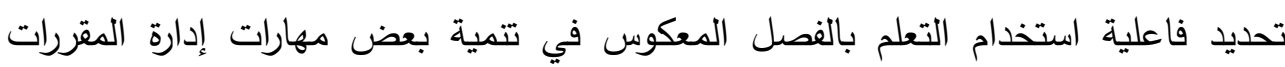
الالكترونية لاى معلمي الحاسب الآلي بالمرحلة الإعدادية بإدارة شرق المحلة التعليمية،

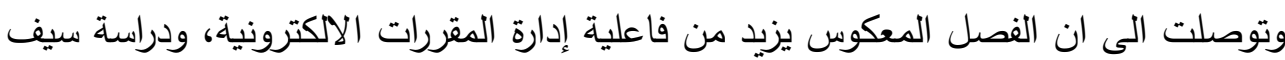

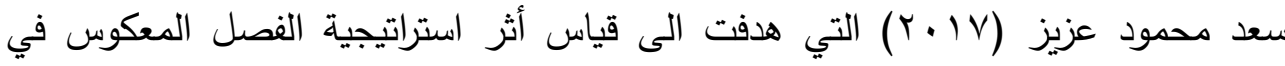

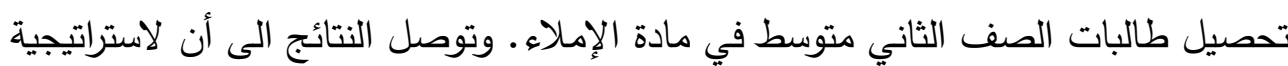
الصف الدقلوب أثرا ايجابياً واضحاً في تحصيل طالبات الصف الثاني متوسط.

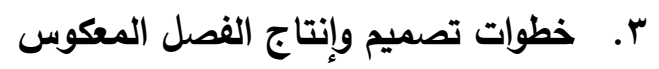

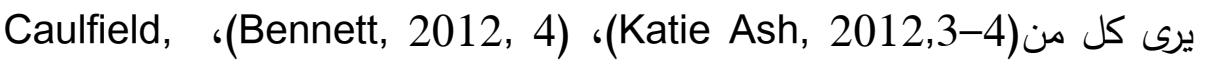
(2011, 15) أنه عند تصميم الدروس التعليمية في الفصل المعكوس يجب أنْ نعمل ما (Bat) 
ا ـ تصــيم أو اسـتخدام الفيـديوهات التعليميـة الخاصــة بمعلـم الفصـل يوضــح المقـرر

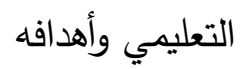

حيث يرى (Giguruwa, et, al. 2012, 166) إنَّ الفيديو التعليمي، إن كان سينقل من خلا الإنترنت، فلابد من أن يؤخذ حجم الفيديو بنظر الاعتبار ، وذلك أن الحجم سيحدد إندا

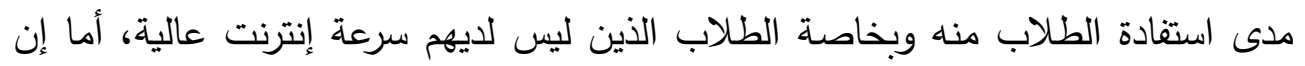

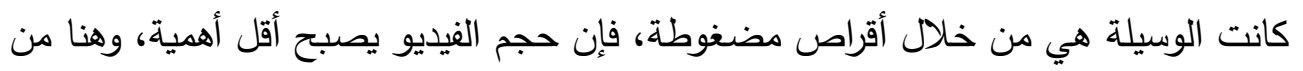
الممكن التفكير بعدد من الاعتبارات والتي قد يكون بعضها أو أحدها مناسبًا أكثر من الآخر لكل بيئة تعليمية وموقف تعليمي. ومن هذه الاعتبارات: - وضع الفيديو المنتج على المدونات الثخصية. - استخدام الخوادم Servers الخاصة بالمدرسة أو بالمنطقة التعليمية لرفع الفيديو. - استخدام مواقع مثل اليوتيوب YouTube. Com - المواقع الإلكترونية.

- توزيع الفيديو عن طريق أقراص مضغوطة الإلهروله

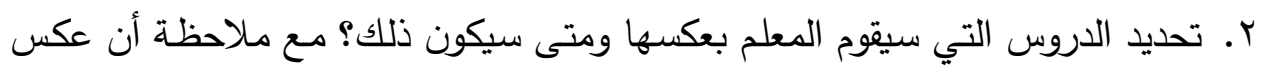
جزه من الدرس لن يجعله درسًا أفضل تلقائياً، وذلك يعتمد على المعلم في أن يكون على دراية بفوائد العملية لصالح طلابه. r. إمكانيـة الحصـول على مـدرس آخر (شـريك) لإنتـاج ملفـات الفيديو، لأن الطـلاب

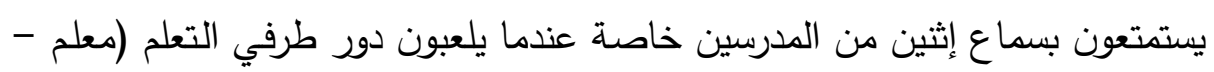
متعلم) ع. البحث عن طرق لإشراك الطلاب في إنتاج الفيديوهات التعليمـة، لأن مجرد مشـاهدة الطلاب للفيديوهات لا يضمن انخراطهم في العملية التعليمية.

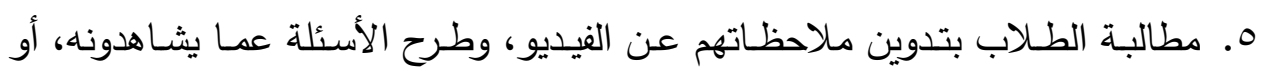

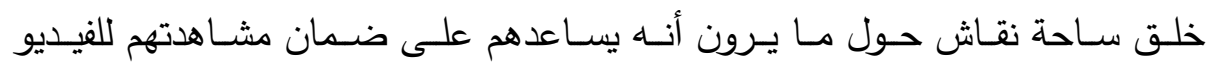
واستيعابهم للمحتوى التعليمي. المحور الثالث: القواعد النحُوية لطلاب المرحلة الثانوية 


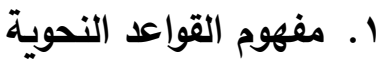

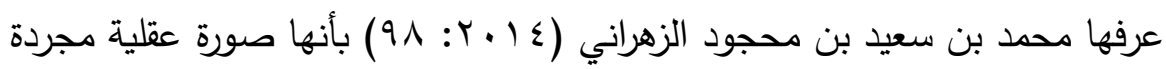
يكونها الطلاب عن الكلمة وبنيتها وعلاقتها بغيرها في الجملة ولها قاعدة تضبط خصائصها وسماتها لتدل على الباب النحوي الذي تتتمي اليه بحيث يمكن تميزها عن غيرها، والحكم على الثاذ، لخروجه عنها بشكل واضح مميز .

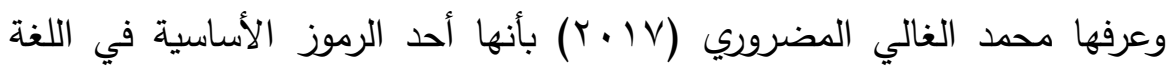

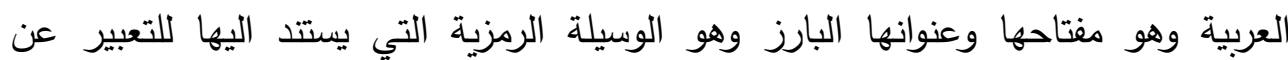
الأفكار والتصورات بغرض عرضها على الطلاب المتلقين وهو كل ما يمكن تصوره من أشياء ومعان مختلفة ملموسة او محسوسة.

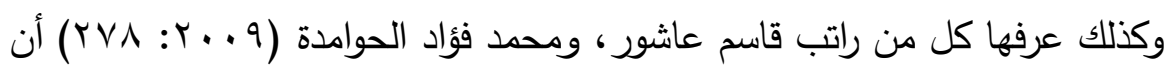
المفاهيم النحوية، هو مجموعة من الأشياء أو الرموز أو الأحداث المعينة، التي جُمعت معًا، على أسس في الخصائص المشتركة والتي يثار اليها باسم او رمز خاص.

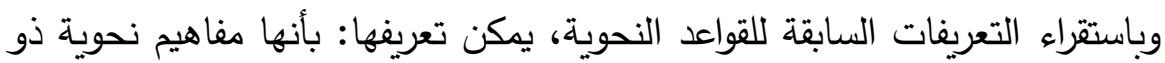
دلالة لفظية لغوية تتعلق بنظم الكلام وتركيبه يكونها طلاب الصف الخامس الثانوي العلمي للمصطلحات النحوية المقررة عليهم لها قاعدة تضبط خصائصها وسماتها وتحدد معناها بحيث يستطيع تميزها وتصنيفها عن غيرها من المفاهيم ويمكن قياسها بأداة معدة لهذا الغرض. r. أهمية تحصيل القواعد النحوية للمرحلة الثانوية:

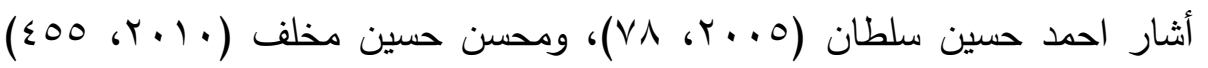
إلى أهمية القواعد النحوية وهي كالآتي: أ. معرفة القواعد النحوية تفتح باب المعرفة الصحيحة لاستخدام اللغة. ب. تعلم القواعد النحوية يسهم في تعلم مفاهيم المواد الأخرى المتصلة بتعلم اللغة. ج. القواعد النحوية تساعد في الوصول إلى فهم عميق لطبيعة المادة النحوية. د. القواعد النحويـة تمكن من التوسع في تحقيق التواصل الفكري والثقافي، وتثكيل تراث اللغة والنحو. 
هـ فهم القواعد النحوية تكسب الطالب قوة التعبير ودقته وتوصيل الأفكار بسهولة.

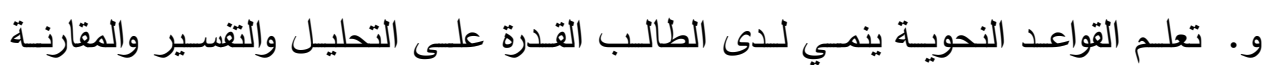
والتصنيف والتمييز وإدراك العلاقات. ز. اتقان مهارات اللغة العربية وتتمية القدرة على القراءة والتعبير. r. الطرق والاتجاهات الحديثة في تدريس القواعد النحوية: ومن الطرق الحديثة في تدريس المفاهيم النحوية التي أثار إليها كل من، طه علي

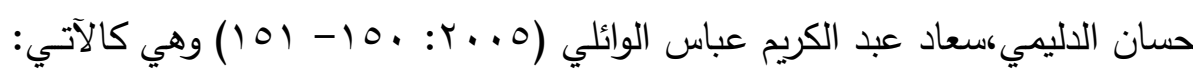

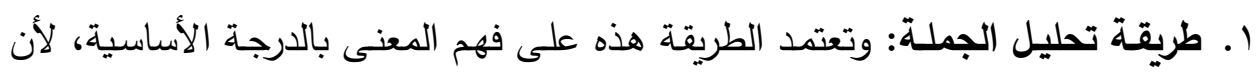
فهم المعنى ييسر للطالب الوصول إلى تحديد موقع اللفظة أو الجملة من الإعراب.

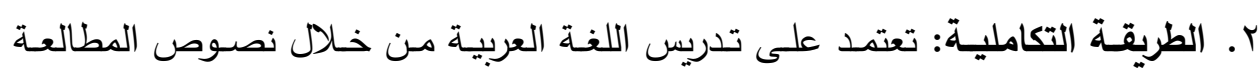
كوحدة متماسكة لأن النصوص مادة صالحة للمطالعة والتعبير الثفوي والكتابي.

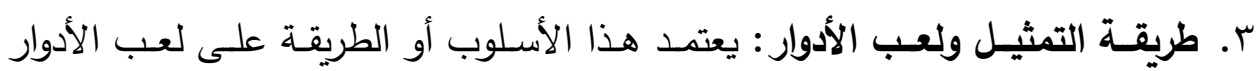

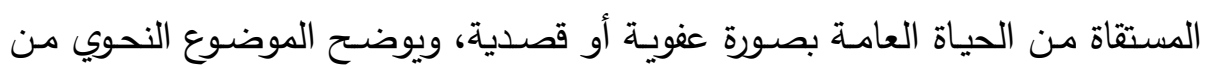
خلال لعب الأدوار من جهة، واختيار فهم الطلاب للقاعدة النحوية من جهة أخرى.

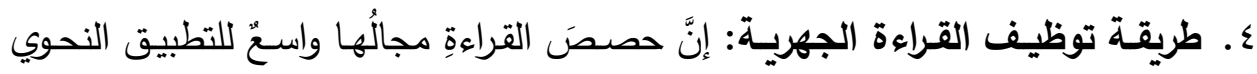
وفهم القواعد وتدريب الطلاب على سلامة اللفظ وضبط القراءة السليمة. ه. طريقة الرسوم البيانية: وتعتمد هذه الطريقة على تقديم المفاهيم النحويـة على شكل

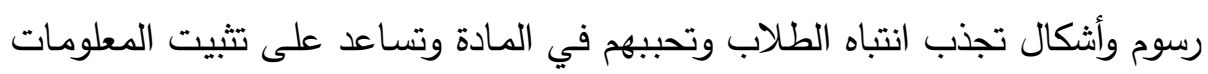
في أذهانهم، لإدراكها عن طريق الحواس المختلفة.

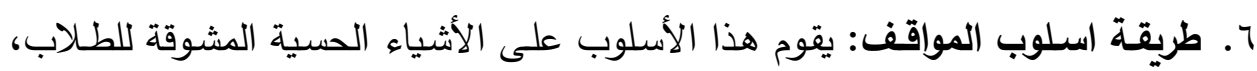
والتي تكوِّنُ لديهم دافعاً قوياً لمتابعة الدرس مع المعلم ومشاركتهم بفاعلية أثناء الدرس. فمن خلال العرض السابق لطرق تدريس القواعد النحوية، يرى الباحث أن كل هذه

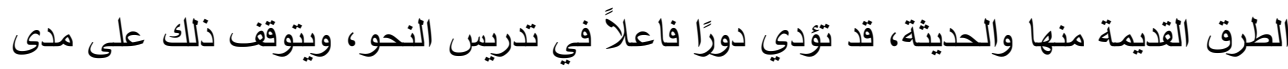
قدرة المعلم على اختيار الطريقة المناسبة للموضوع الذي سيقدمه، وبحسب قدرات الطلاب 
ومستوياتهم، ويرى انَّ بيئة التعلم الآكتروني القائمة على الفصل المعكوس ستوفر تعلم فعال

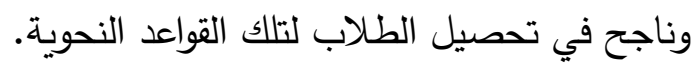

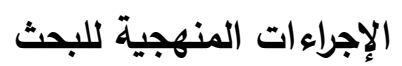

في هذا الفصل يتناول الباحث مجموعة من الخطوات والإجراءات لتصميم البيئة

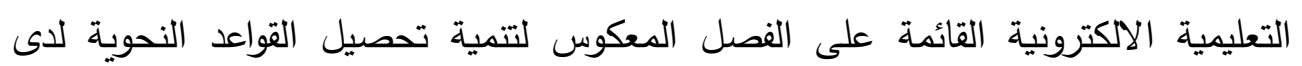

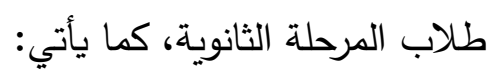

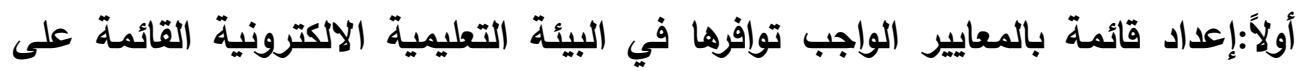

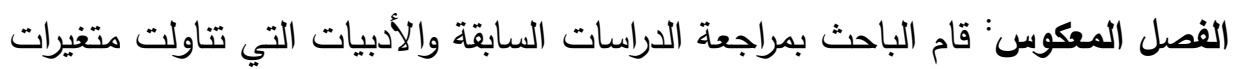
البحث الحالي ووضعت قوائم معيارية لتصميم برامج بيئات التعلم الالكتروني.

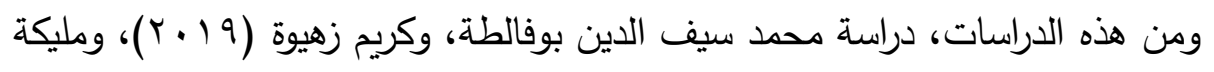

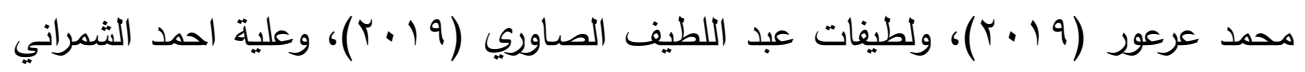

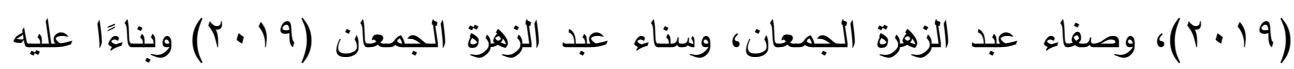

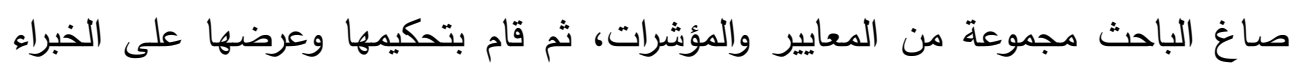

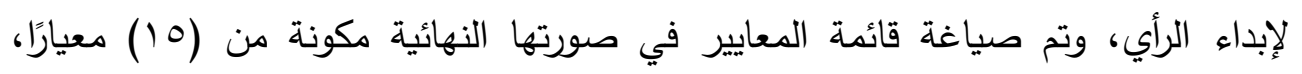
و (10) مؤشرًا).

ثالثا: إعداد الاختبار التحصيلي: قام الباحث بإعداد وتصميم اختبار للتحصيل المعرفي في

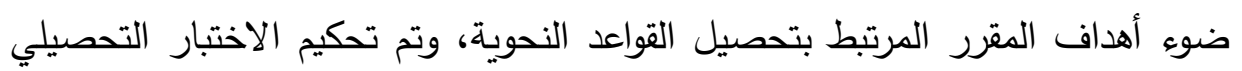

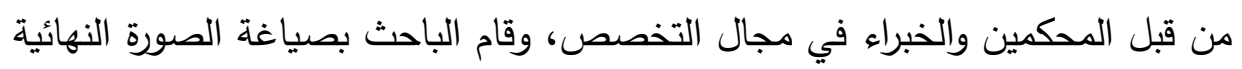

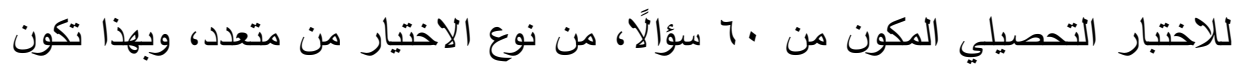

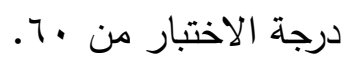

رابعا: إعداد بطاقة مطابقة البيئة التعليمية الاكترونية وتحكيمها: قام الباحث بتصنيف بنود البطاقة، وصياغتها، بحيث تتضمن البطاقة قياس ب ب مغردة، والتي أعدها الباحث مسبقا

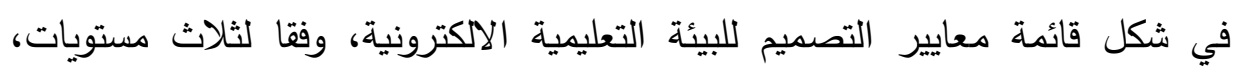
مطابق،الى حد ما،وغيرمطابق،وقام بتحكيمها لاى الخبراء والمتخصصين، وتم صياغتها في صورتها النهائية مكونة من (10) معيارًا، و( (10) مؤشرًا). 
خامسا: التصميم التعليمي للبيئة التعليمية المقترحة:

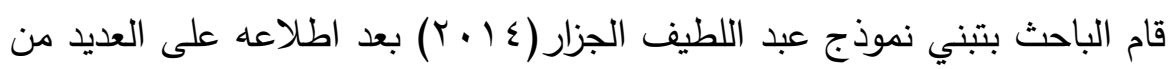

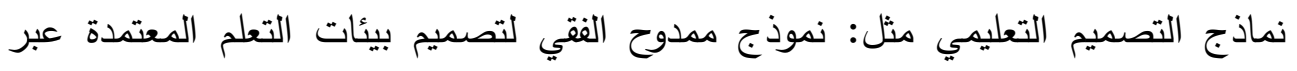

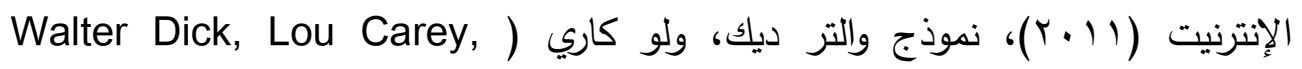

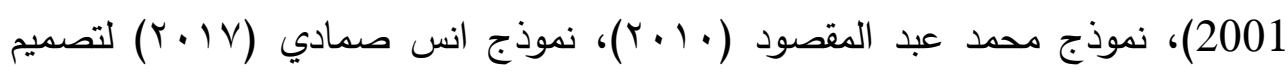

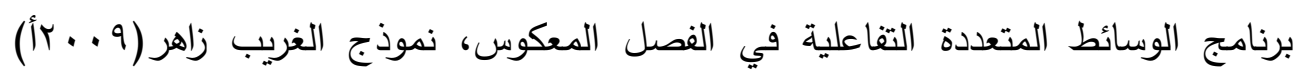

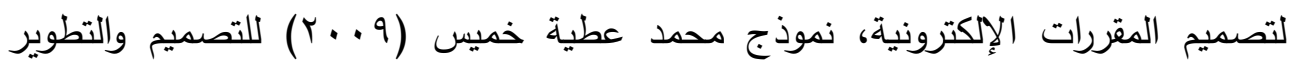

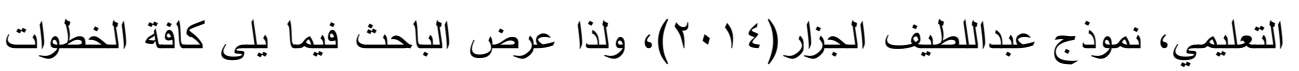

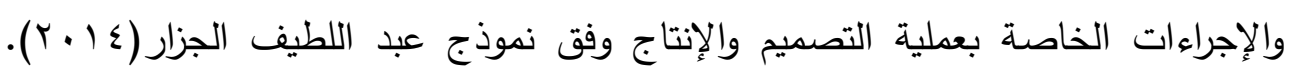

$$
\text { وهي: }
$$
المرحلة الأولى: مرحلة الدراسة والتحليل: وفيما يلي عرض هذه الإجراءات:

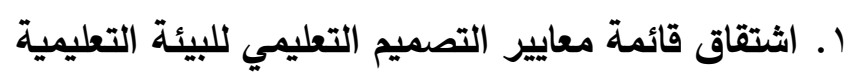

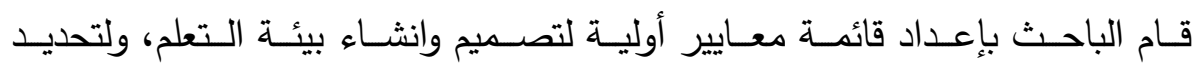
خصائصها. وتكونت تلك القائمة من ثلاثة مجالات، حيث جاء الماءئ المجال الأول منها بعنوان:

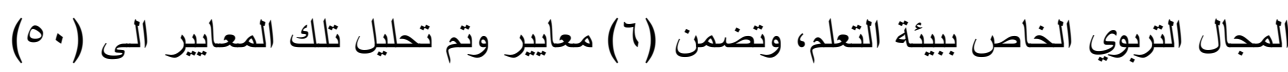

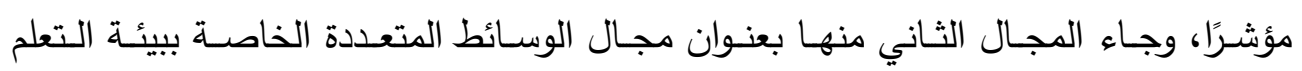

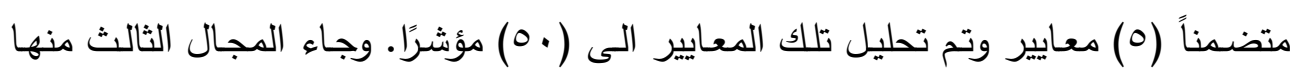

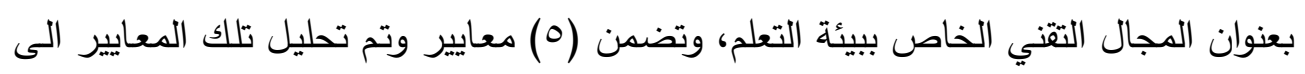

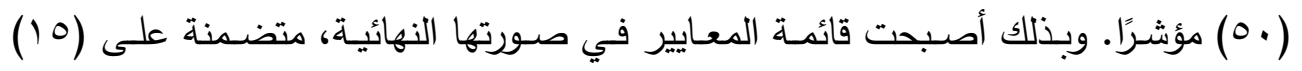

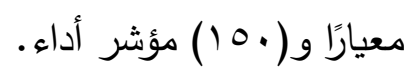

r. ت. تحديد خصائص طلاب الصف الخامس الثانوي (الفرع العلمي):

تم تحديد خصائص الطلاب وتوصيفهم، وذلك للآتي: - طلاب الصف الخامس الثانوي (الفرع العلمي) بمدرسة إعدادية غرناطة للبنين، وتحديد

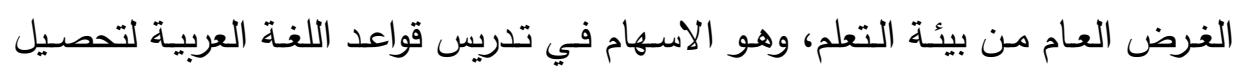
الطلاب المفاهيم النحوية المقررة لديهم. 
- جميع الطلبة لم يسبق لهم دراسة القواعد النحوية عبر بيئات تعلم الكترونية.

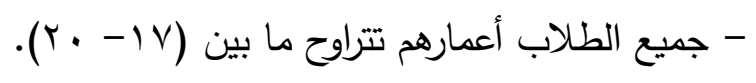
- تتوافر لديهم متطلبات الدراسـة عبر الإنترنت مثل تحميل البرامج من الإنترنت، البحث داخل مواقع متخصصـة في موضـوع مـا، وإنثـاء واستخدام البريد الإلكتروني، وتبـادل

الملفات، وحفظها على الكمبيوتر ، والتعامل مع برنامج معالجة النصوص.

r. تحديد المشكلة وتقدير الحاجات التعليمية من البيئة التعليمية.

تم تحديد المشكلة من خلال الملاحظة المباشرة من خلال تدريس الباحث للمقرر،

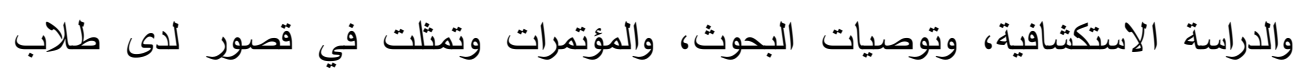
الصف الخامس العلمي، وفي هذه الخطوة، تم تحديد الحاجات التعليمية من بيئة التعلم القائمة على الفصل المعكوس، وذلك عن طريق مقارنة الواقع الحالي بالمستقبل المرتقب، وقد تمثلت الحاجة التعليمية للبيئة التعليمية القائمة على الفصل المعكوس في حاجة طلاب الصف الخامس الثانوي (الفرع العلمي) إلى تعلم اللغة العربية وتحصيل قواعدها النحوية، وذلك لأنها أحد المتطلبات الرئيسة في هذا البحث، وكذلك لمواكبة التطورات الحديثة في عصرنا الحالي للنهوض بالواقع التعليمي، وكذلك لسوء الأوضاع بدخول فيروس كورونا وما رافقه من اغلاق تام للمؤسسات التربوية عامة. ؛ . تحليل مصادر التعلم

- - الامكانيات والأجهزة المتاحـة: إن بيئة التعلم الاككتروني قائمـة على الويبب، وتعتمد

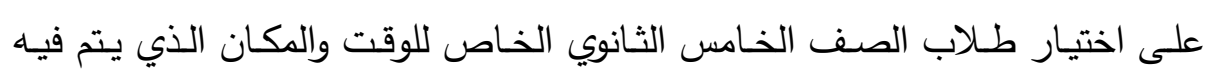
التطبيق، وبالتالي سوف تكون بيئة التعلم متتوعة وفقا لاختيار كل طالب، وذلك في لئي

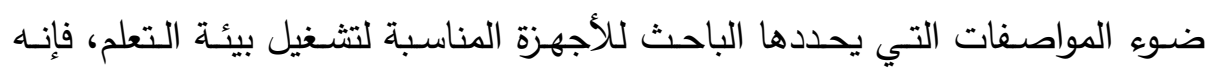
تتوفر لديهم أجهزة الكمبيوتر والهواتف الذكية ومتصلة بالإنترنت.

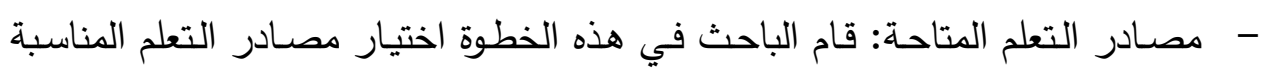

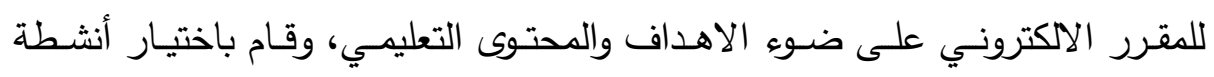
متتوعة، حتى يشعر الطلاب بالتتوع، والتجديد في ممارسة تعلمهم، من خلاد البيئة 
التعليمية الاكترونية، وتثتمل مصادر التعلم على النص المكتوب، الصوت، الصور، مقاطع الفيديو، برنامج التأليف والانتاج، وتوضح كما يلي: المرحلة الثانية: مرحلة التصميم: تعتبر هذه المرحلة من أهم المراحل الخاصة ونية بالنموذج؛ وذلك نظراً لأنها تحتوي على مجموعة الإجراءات والخطوات التي تم اتباعها عند

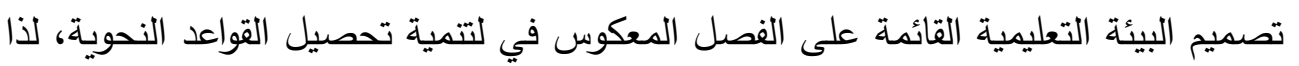
تم إجراء تلك الخطوات والإجراءات الفرعية في ضوء المعلومات التي تم الحصول عليها من مرحلة الدراسة والتحليل، وفيما يلي عرض هذة الإجراءاء تلاء :

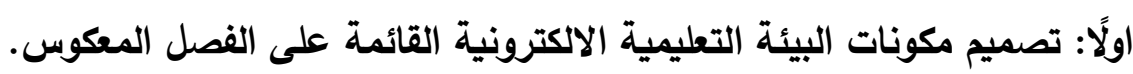
تم توضيح مكونات البيئة التعليمية القائمة على الفصل المعكوس، وهي كما يأتي: 1. اشتقاق الأهداف التعليمية وصياغتها في شكل ABCD، وتحليل الأهداف. يهدف البحث الحالي إلى تتمية تحصيل طلاب المرحلة الثانويـة للقواعد النحويـة من خلال البيئة التعليمية، وفي ضوء ذلك تم صياغة الأهداف التعليمية لهذه البئئة، كالآتي: أ. تتمية تحصيل طلاب الصف الخامس الثانوي للقواعد النحوية. ب. دعم عمليـة التفاعل بين الطـلاب والمعلمين والمسـاعدين مـن خـلال تبـادل الخبـرات التربوية والآراء والمناقثات والحوارات الهادفة لتبادل الآراء بالاستعانة بقنوات الاتصال المختلفة كالبريد الالكتروني والمحادثة والفصل المعكوس. ج. تطوير دور المعلم في العملية التعليمية حتى يواكب التطورات العلمية والتكنولوجية المستمرة والمتلاحقة. د. ت توفير الوسـائل التعليمية (صوت، فيديو، صسور ، أشكال وخرائط، رسوم ثابتة ورسوم متحركة، مما يساعد على فهم الأفكار والموضوعات المراد تعلمها. هـ خلق بيئة تعليميـة تفاعليـة من خـلال تقنيا ت إلكترونيـة جديدة، والتتوع في مصـادر المعلومات والخبرة. وقد قام الباحث بتقسيم محتوى البيئة التعليمية القائمـة على الفصل المعكوس إلى ستة موديولات تعليمية، حيث يقوم الموديول الأول بتحقيق الهدف الأول، ويقوم الموديول الثاني بتحقيق الهدف الثاني، وهكذا حتى الموديول السـاد الذي يحقق الهدف السـاد،، 
ولما كان نموذج الجزار يتطلب صياغة هذه الأهداف التعلمية العامـة للبيئة سلوكيًا حسب

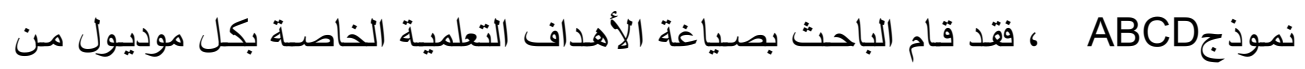
الموديولات الستة، بحيث تصف أداء الطالب، وتكون قابلة للقياس والملاحظة، والبعد عن

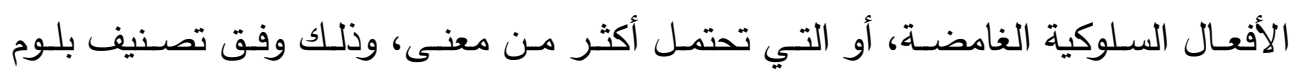

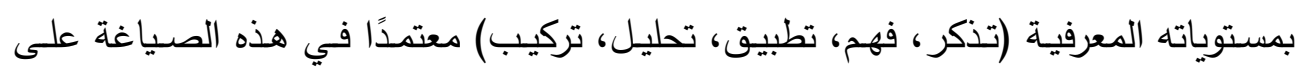

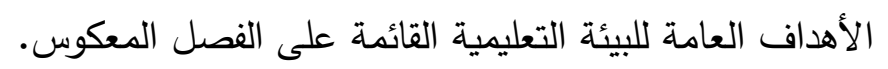

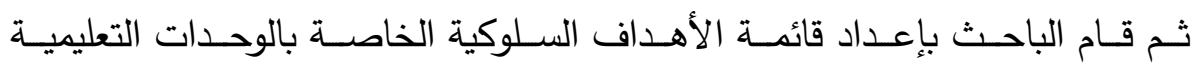
المستخرجة مـن كتاب قواعد اللغـة العربية الصف الخـامس الثانوي (الفرع العلمي)، وذلك بكائك للتوصل إلى النتائج التعليمية الصحيحة وفقاً للنموذج المستخدم

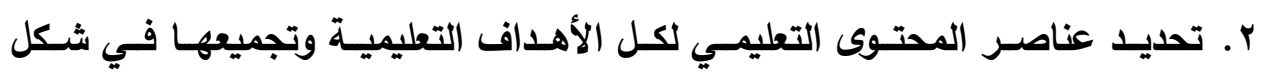
موديولات.

تم تحديد عناصر المحتوى التعليمي في هذه الخطوة، والتي تحقق الأهداف التعليمية المرجوة من البيئة التعليمية القائمة على الفصل المعكوس، وتم اشتقاق هذه العناصر من تلك الأهداف، حيث توصل الباحث إلى عناصر المحتوى الخاصـة بكل موديول من موديولات البيئة، وتم تقسيم عناصر المحتوى إلى ستة موديولات تعليمية وهي كالتالي: الموديول الأول: التوابع في اللغة العربية. الموديول الثاني: النعت(الصفة) في اللغة العربية. الموديول الثالث: العطف في اللغة العربية. الموديول الرابع: البدل في اللغة العربية. الموديول الخامس: العدد (تذكيره وتأنيثه) في اللغة العربية. الموديول السادس: العدد (تعريفه وتتكيره وكناياته) في اللغة العربية.

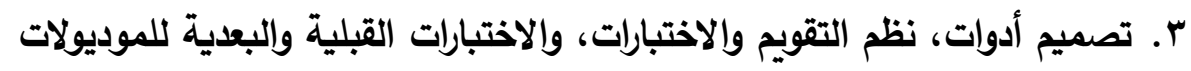

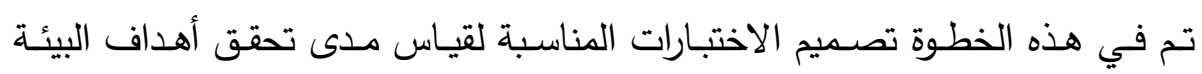
التعليمية القائمة على الفصل المعكوس المصممة في ضوه الفصل المعكوس، حيث تضمن

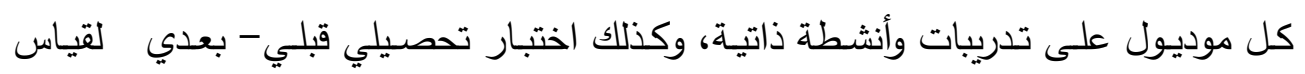


تحصيل الطلاب للقواعد النحويـة المقررة، وكذلك بطاقة مطابقة البيئة التعليمية القائمـة على الفصل المعكوس لقائمة المعايير الخاص بالتصميم.

ع. تصميم خبرات وأنشطة التعلم: المصادر والأنشطة، تفاعلات المتعلم ذاتيًا.

وتعتمد عملية تصميم الخبرات والأنشطة التعليمية الخاصـة بالموديولات علي مجموعة الأهداف التعليمية التي سبق تحديدها، حيث يتم تصميم خبرة أو مجموعة خبرات تعليمية لكل هدف تعليمي، واعتمد اثناء التطبيق على برنامج Google Meet لشرح المحاضرات ومشاركتها مع الطلاب وبرنامج Google Classroom في عملية التعلم الذاتي في أثناء تنفيذ الأنشطة التعليمية المتضمنة داخل الموديولات التعليمية، وأيضـاً أسلوب التعلم الفردي في أثناء قيام الطلاب بحل الاختبارات الموجودة داخل الموديول، وأسلوب المحاضرة الفعالة من خـلا توظيف برنامجGoogle Meet وعرض المعلومات والأمثلة بواسطة مشاركة

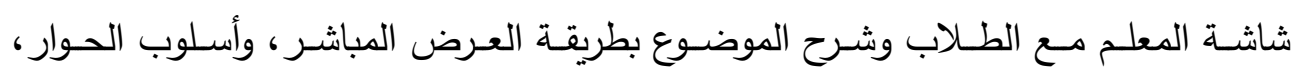
والنقاش، وحل المشكلات، ويتم النقاش والحوار من خلال برنامج Google Meet، وبرنامج

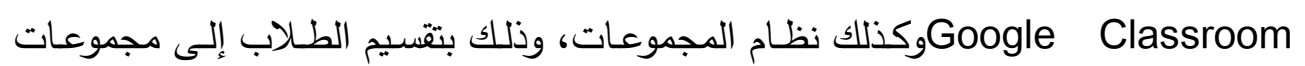

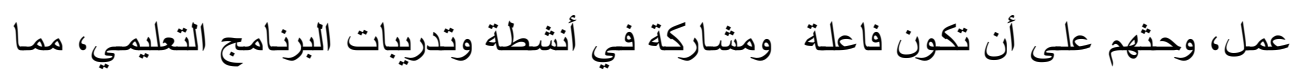
يترك أثرًا إيجابياً لدى الطلاب عينة البحث.

\section{ه. تصميم الرسالة/المحتوي أو السيناريوهات للوسائط والأنشطة.}

فقـد تم في هـه الخطـوة تصـميم المحتوى التعليمي، وكذلك السيناريوهات الخاصة بالبيئة التعليمية القائمة على الفصل المعكوس، حيث يعد السيناريو مخططاً لإنتاج المنتوج التعليمي، ويشمل الخطوات التتفيذية، والثروط والتفاصيل الخاصـة به، وخطوات إعداده، حيث تم ترتيب الأهداف والمحتوى والخبرات التعليمية، ثم كتابة وصف مختصر وموجز للترتيب المحدد، مع رسم مبدئي لتحويل العناصر المكتوبـة إلى عناصر بصرية، مـع

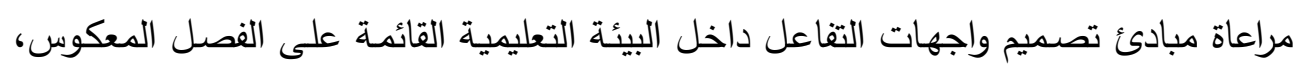
وعناصـر الجذب والتشـويق،وبعد الانتهاء من بنـاء السيناريوهات في صيغتها المبدئية، تم عرضها على مجموعة من الخبراء المتخصصين في مجال (تكنولوجيا التعليم للحكم على صلاحية السيناريو للتطبيق. 


\section{4. تصميم أساليب الإبحار، والتحكم التعليمي، وواجهة المتعلم.}

استخدم الباحث نمط أساسي من أنماط الإبحار أو التفرع داخل البيئة التعليمية القائمسة على الفصل المعكوس وهو: النمط التفريعي: وفيـه يتحرر الطالب من قيود تحكم البيئة التعليميـة القائعـة على الفصـل المعكوس، كمـا هو الحـال عند الدخول لمكونـات الموديول (المقدمـة الأهداف عناصـر المحتوى) أو عند إعـادة دراسـة عناصـر محتوى الموديـول مـرة أخرى فيستطيع الطالب اختيار أي جزء من الموديول لإعـادة دراسته بحريـة، دون الالتزام

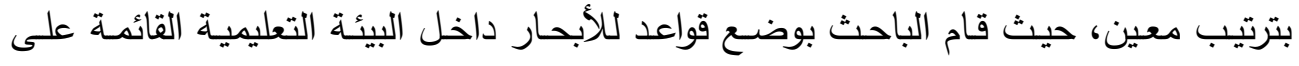

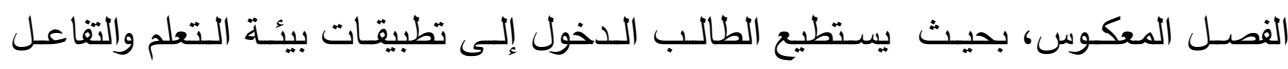
والتشارك مع أقرانه تلقائيًا، ثم الانتقال إلى الاختبار التحصيلي القبلي، ومن ثم التوجه لدراسة الموديول الأول، وبعد ذلك تفعِل بيئة التعلم المهام المراد تعلمها للطالب تلقائيًا، والتفاعل والتثـارك مـع أقرانـه. كمـا راعى الباحث في تصـميم البيئة التعليميـة القائمسة على الفصل

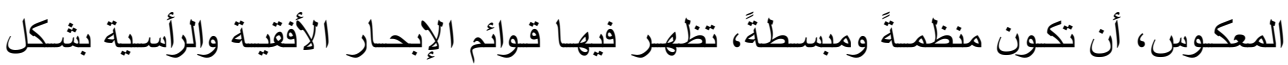
متتاسق مع إتباع إسلوب موحد في عرض المثيرات. كما تضمنت واجهة التقاعل لبيئة التعلّم على عدد من مفاتيح التنقل وقوائم إبحار رأسية وأدوات للتفاعل والاتصـال التعليمي، ساعدت إلت الطلاب في استخدام بيئة التعلّم القائم على الفصل المعكوس بطريقة إثرائية إيجابية، وتفاعلية نحو تحقيق الأهداف التعليمية، على النحو التالي: - مفتاح المقدمـة: والموجود بشكل دائم في القائمسة الرأسية، ويحتوي على عنوان البحث والبيئة التعليمية الالكترونية وأسماء المشرفين واسم الباحث.

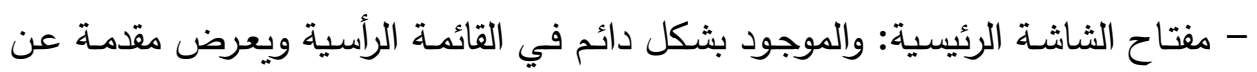
بيئة التعلّم القائم على الفصل المعكوس والأدوات المستخدمة داخلها. - مفتاح الأهداف: والموجود بشكل دائم في القائمة الرأسية ويعرض الأهداف العامـة من

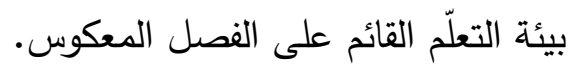
- مفتـاح التقويم: والموجـود بشكل دائم في القائمـة الرأسـية ويعرض تعليمـات استخدام الاختبارات القبلية والبعدية واهدافهما. 
- مفتاح المحتوى التعليمي: والموجود بشكل دائم في القائمـة الرأسية ويعرض صفحة الموديولات الستة في بيئة التعلّم القائم على الفصل المعكوس والتي يختار منها الطالب لتبل

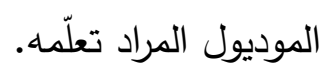

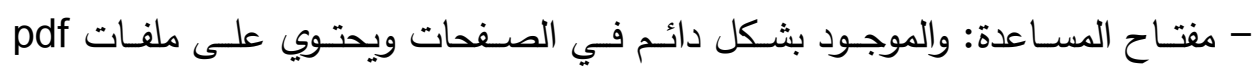
إرشـادات ودليـل اسـتخدام للطالب للـدخول في بيئة التعلم عـن طريـق الكمبيـوتر او

$$
\text { الموبايل. }
$$

- مفتاح التواصل: والموجود بشكل دائم في الصفحات تحتوي بـرامج التواصل مـا بين المعلم وطلابه من خلال الانستغرام والفيس بوك وتويتر وجيميل وواتس آب ويوتيوب.

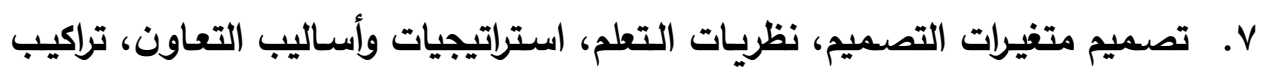

\section{وتنظيم المحتوي والأنشطة وإدارتها:}

تم في هذه الخطوة تصميم واجهات التفاعل الخاصة بالبيئة التعليمية القائمة على الفصل المعكوس، وذلك من خلال الاعتماد على معايير التصميم التي اشتقت من خلال الاطلاع على الأدبيات والدراسات والأبحاث، وذلك على النى النحو التالي:

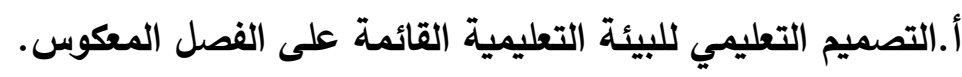

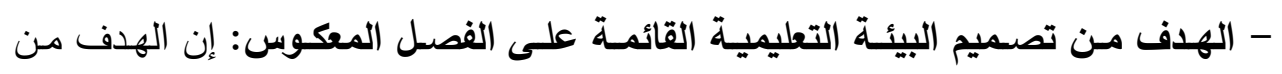
التصميم هو مدى قياس فاعلية البيئة المصصممة، هو لتتمية تحصيل القواعد النحويـة لدى طلاب المرحلة الثانوية. - تصميم الواجهة الخاصـة بالبيئة التعليمية القائمـة على الفصل المعكوس: تم تصميم

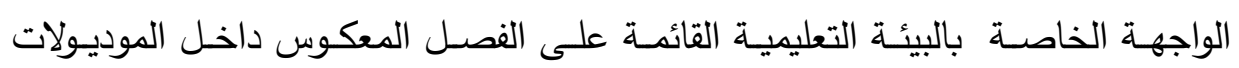
التعليمية، وذلك بعد دراسة كل موديول تتنقل بجلسة مباشره مع معلم المادة من خلال

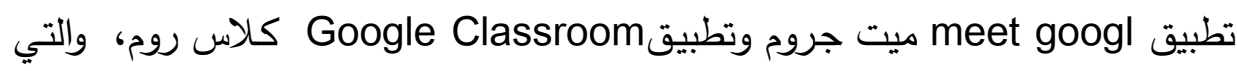
اقتصر البحث الحالي عليهما في واجهة البيئة، حتى يستطيع الطلاب في أثناء دراستهم

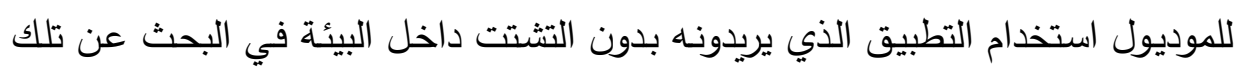

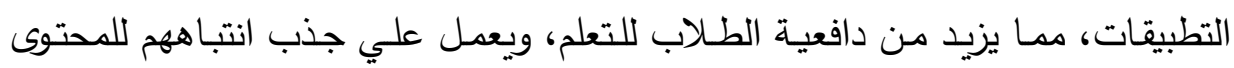
المقدم لهم. 
^. تحديد وتصميم أدوات الاتصال المتزامن وغير المتزامن داخل البيئة التعليمية. إن التقاعلات هي التي تجعل عملية التعلم ذات طابع إيجابي ونشط، فهي تعمل على ترفيه المتعلم، وتساعده على التواصل المستمر بينه وبين المعلم وبينه وبين زملائه فى أي وقت وفى أى مكان، واعتمد الباحث في هذه الدراسة على نوعين من أنماط التفاعل، وهما: (أنماط التفاعل المتزامن، وأنماط التقاعل غير واعن المتزامن). 9 . . تصميم نظم تسجيل الطلاب، وإدارتهم، وتجميعهم، ونظم دعم الطلاب.

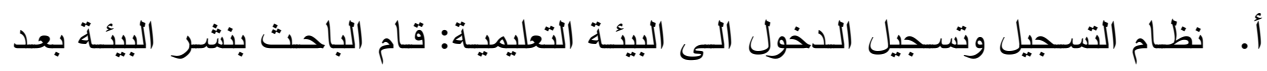

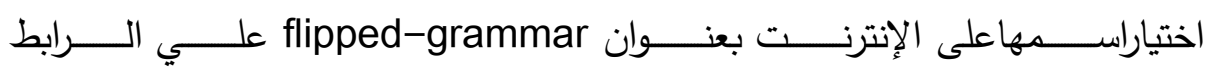
https://sites.google.com/view/flipped-grammar إلى الطلاب عبر البريد الإلكتروني الخاص بهم المسجل على جهات اتصال جوجل، ثم الاخول مباشرة الى بيئة التعلم الرقمي الافتراضي من غير تسجيل السم مستخدم أو

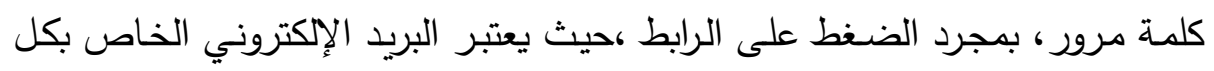
منهم هو حساب المستخدم علي البيئة. ب. دعم الطلاب في البيئة التعليمية: تم تقديم عديد من أساليب الدعم والمساعدة للطلاب لتيسير التعامل مع البيئة التعليمية القائمة على الفصل المعكوس كالآتي:

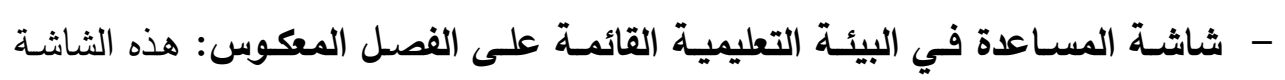
تمكن الطـلاب مـن الحصـول على المسـاعدة اللازمــة لاسـتخدام البيئسة وكيفيـة عمـل

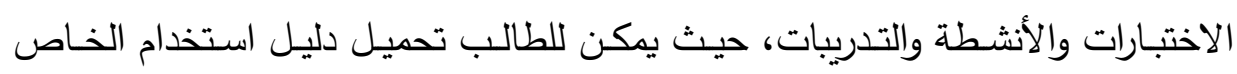
بالبيئة والخاص ببرنامج Google Meet وبرنامج Google Classroom، وكذلك

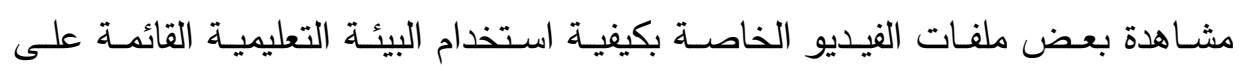
الفصل المعكوس، وكيفية استخدام أدوات التفاعل. - شاشــة الاتصـال بنـا: تحتوي هذه الشاشـة على نموذج مراسلة يمكن من خلالهـ تعبئة

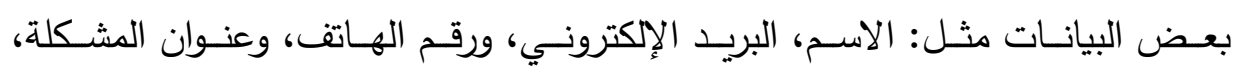

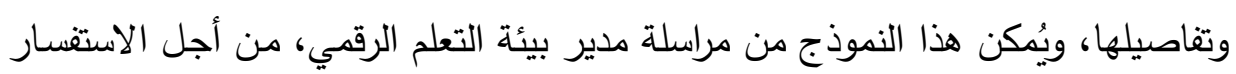
وإرسال المقترحات والتعليقات. 
• 1 . تصميم بيانات ومعلومات والمخطط الثكلي (Layout)لعناصر البيئة، ويشمل:

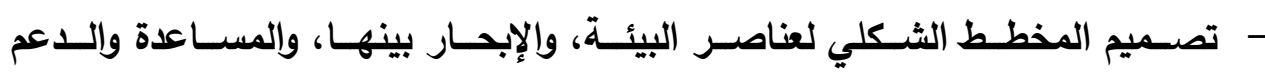
والإرشاد:حيث تم تصميم المخطط الثكلي لعناصر بيئة التعلم الرقمي الافتراضي القائع على الفصـل المعكوس، بحيـث أن واجهـة البيئة تســح بتقديم التعليمـات والتوجيهات والإرشادات التي يتفاعل معها الطالب من خلال عملية الإبحار والتجول بين عناصر واجهة التفاعل لبيئة التعلم الرقمي الافتراضي.

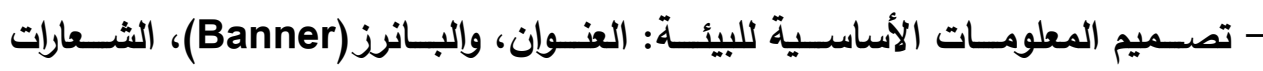

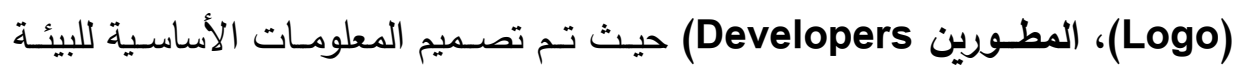
التعليميـة القائمسة على الفصـل المعكوس، وذلكك في ضـوه معـايير التصـميم التـي تم اشتقاقها، حيث تم وضع لوجو مميز ومعبر عن المحتوى الالكتروني المقدم، وكذلك تم

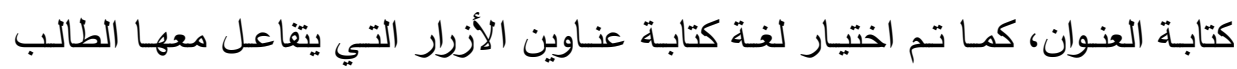
للتجول داخل البيئة التعليمية بسهولة. المرحلة الثالثة: مرحلة الإنتاج والإنثاء: تم في هذه المرحلة الحصول على المواد

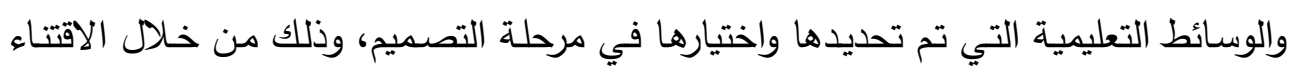

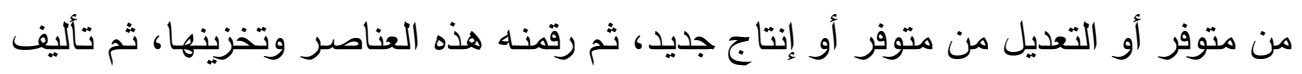
البيئة وتصميمها وتنفيذ السيناريو المعد، وبعد ذلك تم رفع البيئة التعليمية علي الخادم الذي هني

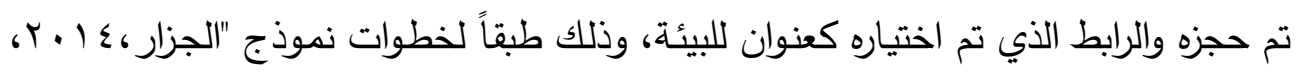
المستخدم في تصميم البيئة التعليمية المقترحة على المساحة المحجوزة والمخصصـة للموقع على مزود خدمـة الإنترنت، وفى النهايـة تشطيب النموذج الأولى للبيئة وعمل المراجعات

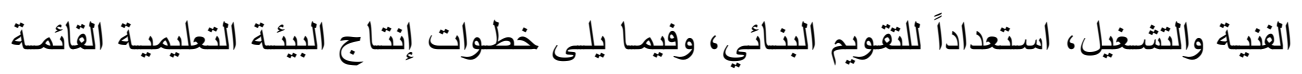

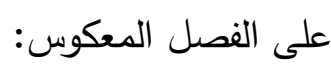
ا ـ انتاج عناصـر الوسـائط المتعددة للبيئة التعليميـة، والمصـادر والأنشطة: تـم في هذه المرحلة تتفيذ السيناريو للبيئة التعليمية القائم على الفصل المعكوس، وإنتاج عناصرها التعليمية التي يشتمل عليها السيناريو، وذلك باستخدام الأدوات المناسبة لكل عنصر 
r. رقمنه وتخزين عناصر الوسائط المتعددة لعناصر البيئة التعليمية: في ضوء الخطوات السابقة تم الحصول على بعض الرسوم والصور ولقطات الفيديو التي تم إنتاجها حيث أنه تم إنتاج جميع لقطات الفيديو وقد قام الباحث بتصميم وبرمجة بيئة التعلّم القائم

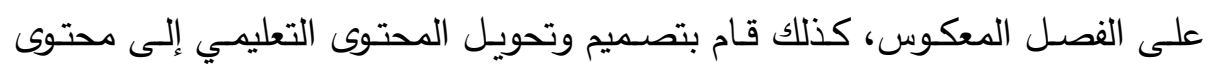
إلكترونـي وفق المواصـفات الفنيـة والتربويــة وقد استخدم الباحث العديـد مـن البـرامج

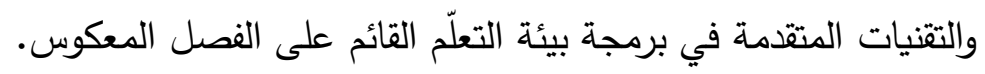

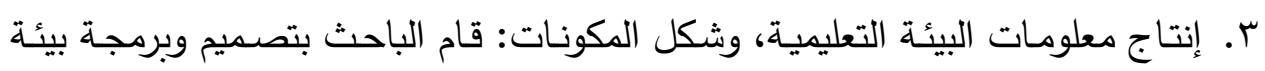

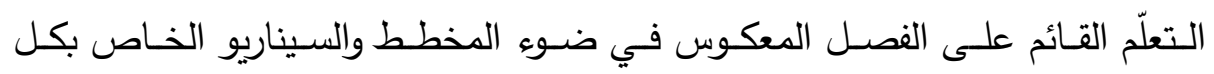
موديول.

ع. إنتاج النموذج الأولي للبيئة التعليميـة: بعد الإنتهاء مـن إنتاج النسخة الأولية للبيئة

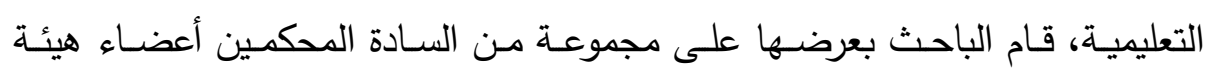
التدريس تخصص تكنولوجيا التعليم والمناهج وطرق التدريس بالإضـافة إلى تخصص مص علوم الحاسوب وتكنلوجيا المعلومـات، للتأكد من مناسبتها للأهداف التعليميـة، وتم تحليل هذه الآراء وأخذها في نظر الإعتبار واجراء التعديلات اللازمة في ضوه التقويم البنائي.

المرحلة الرابعـة: مرحلـة التقويم البنـائي وصـلاحية البيئة في ضوء المعايير: قام الباحث فى هذه الخطوة وفقاً لنموذج الجزار بضبط البيئة التعليمية، والتأكد من سـلامتها، وتقصيلها كالآتي: أ. ـ طبق على أفراد أومجموعات من المتعلمين وعمل التقويم البنائي للبيئة، وعمل التحكيم للتأكد من مطابقتها لمعاييرالتصميم، ويمكن بذلك استخدامها في البحوث التطويريـة، وفي هذه المرحلة تم إعداد بطاقة مطابقة المعايير ، وعرض البيئة التعليمية القائمـة على الفصـل المعكوس لتنميـة تحصيل القواعد النحويـة على مجموعـة مـن السـادة المحكمين والمتخصصين في مجال تكنولوجيا التعليم، وذلك للتأكد من مطابقتها لهذه

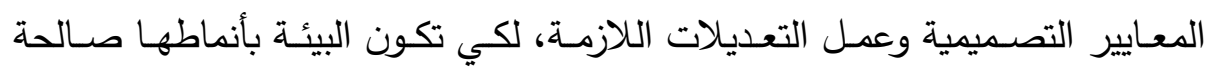

$$
\text { للتقويم الجمعي/ النهائي. }
$$


وفي ضوء آراء وتوجيهات السادة المحكمين ومراجعة السادة المشرفين تم إجراء التعديلات اللازمة للبيئة التعليمية، وأصبحت صالحة للتقويم النهائي. ثم تجريب البيئة التعليمية على عينة استطلاعية صغيرة تتكون من (• (1) طلاب من المرحلة الثانوية. ب. إجراء تقييم موسع نهائي لإنهاء التصميم التعليمي.: قام الباحث بتجريب الموديولات

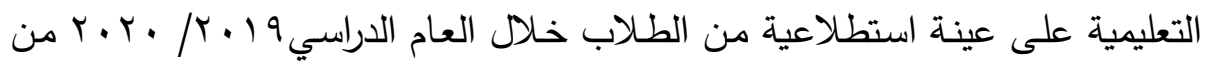
طلاب المرحلة الثانوية. المرحلة الخامسة: مرحلة النشر والاستخدام: بعد الانتهاء من مرحلة التقويم، قام الباحث بنشر موقع بيئة التعلم الرقمي الافتراضي وهو: بttps://sites.google.com/view/flipped-grammar صورته النهائية، وذلك للبدء في التجربة الأساسية للبحث وتطبيقها على طلاب الخامس العلمي، لمعرفة مدى تحصيلهم للقواعد النحوية المقرة في البحث الحالي.وفيما يلي خطوات

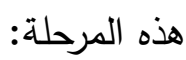

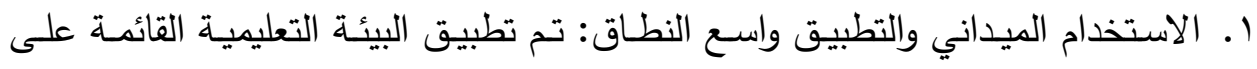

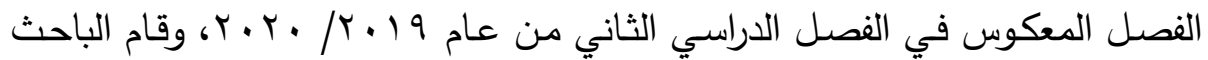
بالثـرح لطـلاب المجموعتين التجربييتين بكيفيـة الدخول إلى الموقع الخـاص بالبيئة باستخدام رابط الموقع الذى تم إعطاؤه لهم، وقام طلاب كل مجموعـة بالدخول إلى الموقع من خلال الرابط الخاص بالبيئة، وبالتالي يستطيع كل طالب الدخول إلى البيئة ومشـاهدة المقرر التعليمسي المقدم لـه سواء في المنزل أو في أي مكان آخـر، ولقد حرص الباحث على المتابعة اليومية للمجموعتين وتلقى الاستفسارات من المجموعات المستخدمة حسب نوع النمط المقدم وتتبع سير الدراسة على الموقع حتى انتهاء جميع المقرر r. المراقبـة المستمرة، وتوفير الدعم والصيانة، والتقويم المستمر : تعد المراقبة المستمرة

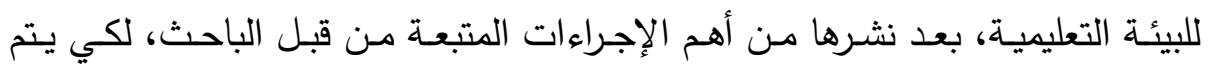
متابعة وتعديل الملاحظات التي تستلزم تعديل البيئة فيها، وللتأكد من عدم حدوث أي الي أخطاء أو مشكلات تعوق الوصول للبيئة، فقام الباحث بمتابعة دخول الطلاب وتتبع 
أنشطتهم، ومتابعة سرعة تحميل الصفحات، ومراجعة ما ينشر على البيئة من ملفات أو روابط، والعمل على تطويرها باستمرار لخدمة الأجيال القادمة. نتائج البحث

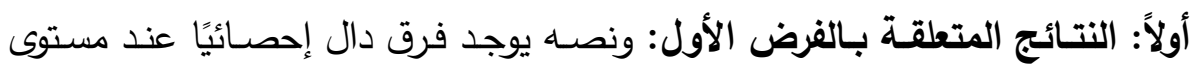

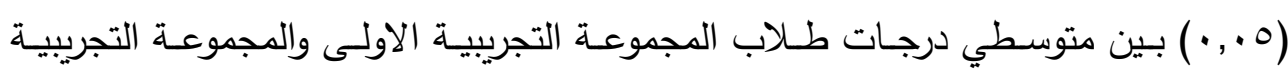
الثانية في التطبيق البعدي للاختبار التحصيلي الخاص بالقواعد النحويـة (الخامس الثانوي) لصالح المجموعة التجريبية الاولى". لاختبار هذا الفرض استخدم الباحث اختبار" ت " للمجموعات المستقلة لتحديد دلالة الفروق بين متوسطي درجات طلاب المجموعة التجريبية الأولى، والمجموعة التجريبية الثانية في التطبيق البعدي للاختبار التحصيلي الخاص بالقواعد النحوية (الخامس الثانوي)، ويتضح ذلك من خلال الجدول التالي: جدول (1) قيمة " ت " ودلالتها الإحصائية للفروق بين متوسطي درجات طلاب المجموعتين التجربيتين التطبيق البعدي للاختبار التحصيلي

\begin{tabular}{|c|c|c|c|c|c|}
\hline مستوى الدلالة & قيمة (ت) & المعياري & المتوسط & المجموعة & أبعاد الاختبار \\
\hline \multirow{2}{*}{$\cdot, \cdot}$, & \multirow{2}{*}{$r V, V \leqslant r$} & $1,91 \leqslant$ & or, IV & التجريبية الأولي & \multirow{2}{*}{ الدرجة الكلية } \\
\hline & & $\varepsilon, 11 \varepsilon$ & $r, r)$ & التجريبية الثانية & \\
\hline
\end{tabular}

من الجدول السابق يتضح أنه:

توجد فروق ذات دلالة احصائية بين متوسطي درجات طلاب المجموعة التجريبية الأولى والمجموعة التجريبية الثانية في التطبيق البعدي للاختبار التحصيلي الخاص بالقواعد النحوية (الخامس الثانوي) لصالح المجموعة التجريبية الأولى (IV, IV)، حيث جاءت قيم

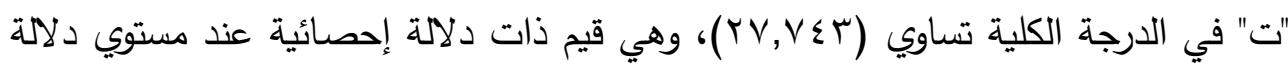
$\cdot \cdot, \cdot 1$

ثانيًا:النتائج المتعلقة بالفرض الثاني: ونصه "يوجد فرق دال إحصائيا عند مستوى (0., • ) بين متوسطي درجات طلاب المجموعة التجريبية الاولى في التطبيقين القبلي 
والبعدي للاختبار التحصيلي الخاص بالقواعد النحوية (الخامس الثانوي) لصالح التطبيق

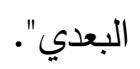

ولاختبار هذا الفرض استخدم الباحث اختبار"T-test" " ت " للمجموعات المرتبطة

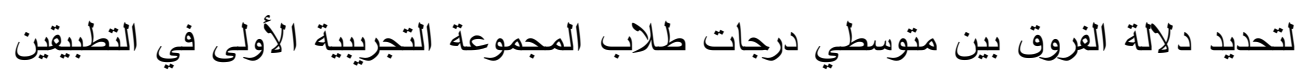
القبلي، والبعدي للاختبار التحصيلي الخاص بالقواعد النحوية (الخامس الثانوي)، ويتضح

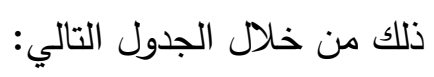
جدول (ץ) قيمة " ت " ودلالتها الإحصائية للفروق بين متوسطي درجات طلاب المجموعة

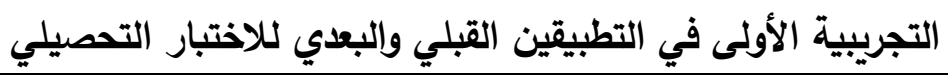

\begin{tabular}{|c|c|c|c|c|c|}
\hline مستوى الدلالة & قيمة (ت) & الانحراف المعياري & المتوسط & التطبيق & المستويات \\
\hline \multirow{2}{*}{$\cdot, \cdot 1$} & \multirow{2}{*}{$\vee \wedge, 7$} & $r, T r V$ & $1 r, 1 \wedge$ & قبلي & \multirow{2}{*}{ الارجة الكلية } \\
\hline & & $1,91 \leqslant$ & or, IV & بعدي & \\
\hline
\end{tabular}

توجد فروق ذات دلالة احصائية بين متوسطي درجات طلاب المجموعة التجريبية

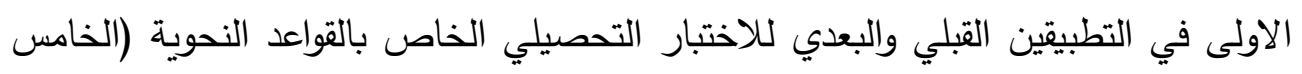

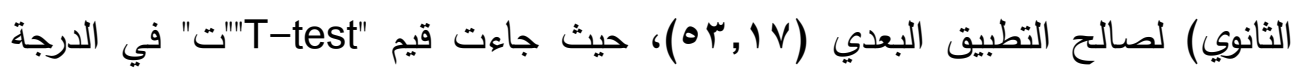

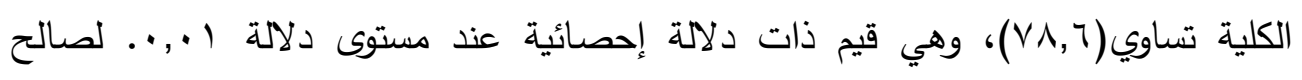
المتوسط الأعلى. • حساب حجم تأثير البيئة التعليمية القائمة على الفصل المعكوس لتنمية التحصيل للى طلاب الصف الخامس.

لبيان قوة تأثير المعالجة التجريبية (البيئة التعليمية القائمة على الفصل المعكوس)

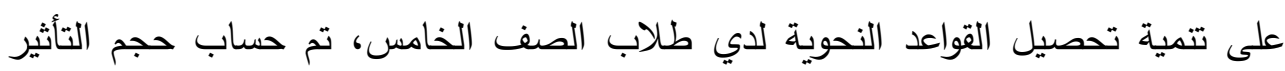

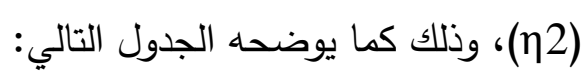

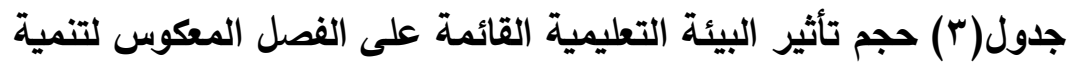

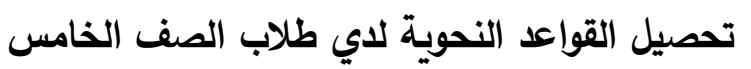

\begin{tabular}{|c|c|c|}
\hline حجم التأثير & قيمة (2) ) & أبعاد الاختبار التحصيلي \\
\hline
\end{tabular}




\begin{tabular}{|c|c|c|}
\hline حجم التأثير & قيمة (2 ) ) & أبعاد الاختبار التحصيلي \\
\hline كبير & •, १9 & الدرجة الكلية للتحصيل \\
\hline
\end{tabular}

يتضح من الجدول السابق أن حجم تأثير البيئة التعليمية القائمة على الفصل المعكوس لتتمية تحصيل القواعد النحوية لدي طلاب الصف الخامس كبير، حيث تراوحت قيم حجم التأثير من (79, •- - 99, • ). وهذا يعني أن نسبة التباين الكلي لدرجات أفراد العينة التي ترجع إلى تأثير المتغير المستقل (فاعلية البيئة التعليمية القائمة على الفصل المعكوس) التي أعدت لمعالجة المتغير التابع (تتمية تحصيل القواعد النحوية). ويمكن تفسيره في ضوء المتغير المستقل وهذا يعني أن حجم تأثير البيئة التعليمية كبير، وتتثق هذه النتيجة

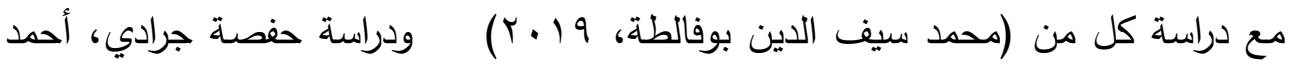

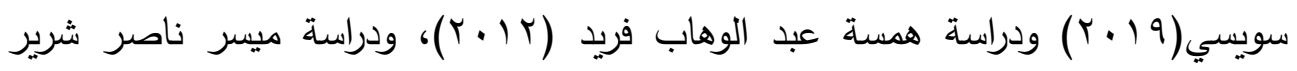

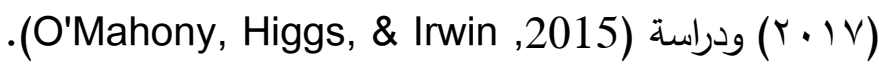
ويرى الباحث أن زيادة التحصيل في البحث الحالي قد يرجع إلى: ا. مراعاة البيئة للفروق الفردية بين طلاب المجموعتين وتلبية احتياجاتهم ومراعاة تقدم كل

$$
\text { طالب على حدة. }
$$

r. التتوع في الأنثطة داخل البيئة التعليمية القائمة على الفصل المعكوس، مما يزيد من

$$
\begin{aligned}
& \text { المتعة والتثويق مع المحتوى الدراسي. } \\
& \text { تفسير النتائج ومناقشتها }
\end{aligned}
$$

يمكن تفسيرالنتائج ومناقشتها في ضوء نتائج التطبيق، وما تم من معالجة إحصائية

$$
\text { للفروض لاختبار صحتها والتوصل إلى النتائج الآتية: }
$$

ا. يوجد فرق دال إحصائيًا عند مستوى (0. . •) بين متوسطي درجات طلاب المجموعة التجريبية الأولى والمجموعة التجريبية الثانية في التطبيق البعدي للاختبار التحصيلي الخاص بالمفاهيم النحوية (الخامس الثانوي) لصالح المجموعة التجربيية الأولى". r. يوجد فرق دال إحصائيًا عند مستوى (0. . • ) بين متوسطي درجات طلاب المجموعة

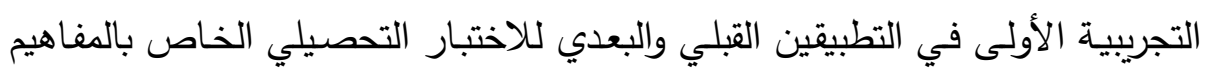
النحوية (الخامس الثانوي) لصالح التطبيق البعدي". 


\section{ويمكن أن يعزى هذا الاختلاف للأسباب التالية:}

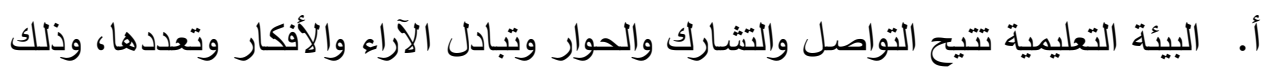
يؤدي إلى إثراء عملية التعلم والتعليم.

وبناءًا على هذه النتيجة، تعتبر الدراسة عبر البيئة التعليمية ذا أثر على التحصيل التيلة التيلية

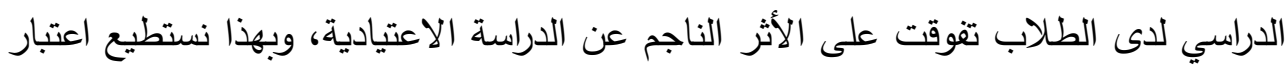

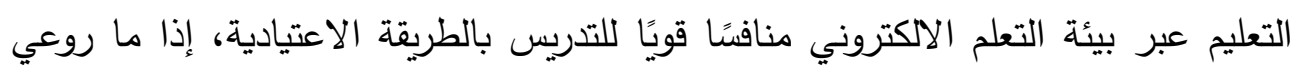

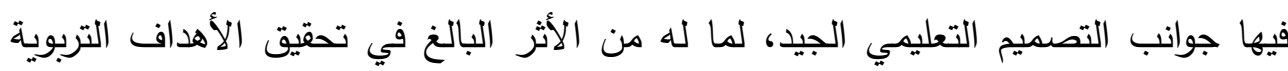

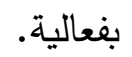

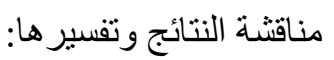
من خلال النتائج السابقة يمكن القول بفاعلية البيئة التعليمية القائمة على الفصل

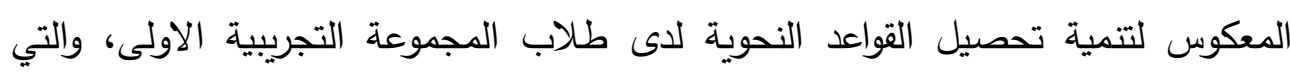
عملت علي زيادة نسبة التحصيل لديهم.

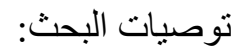

ا ـ تبني البيئة التعليمية القائمة على الفصل المعكوس في التعليم، لتتمية مهارات الطلاب

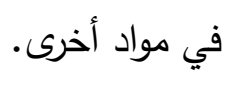

r. استخدام البيئة التعليمية القائمة على الفصل المعكوس في التعليم الثانوي يحقق نجاحًا عاليًا في تتمية التحصيل.

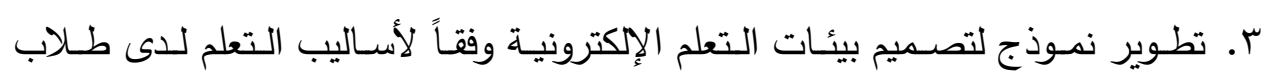
المرحلة الثانوية. المراجع المعام

ابتسام سعود الكحيلي (10 • ب) فاعلية الفصول المقلوبة في التعلم. الدينة المنورة: مكتبة

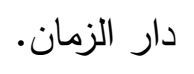

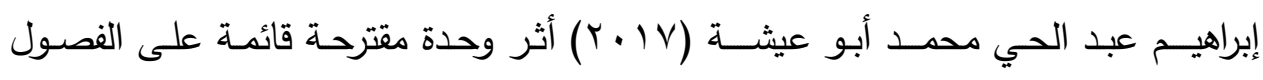

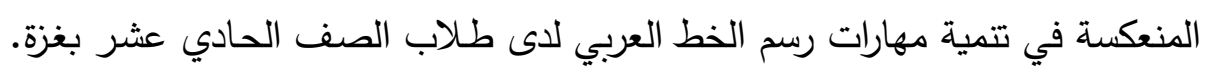

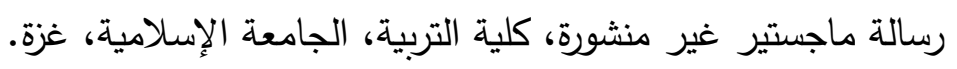


إبراهيم عبد الوكيل الفار (r ( • rأ) تربويات تكنولوجيا القرن الحادي والعشرين: تكنولوجيا ويب (†, (r)، طنطا، الدلتا لتكنولوجيا الحاسبات.

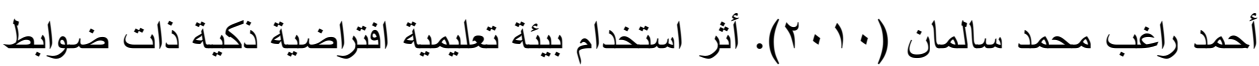
معرفيـة متغيرة على تتميـة التفكير الابتكاري لدي دارسي تكنولوجيـا التعليم. رسـالة دكتوراه. معهد الدراسات التربوية: جامعة القاهرة.

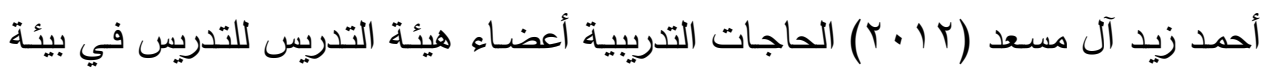

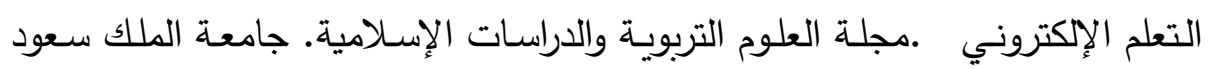

$$
\text { بالرياض: مجلد (ع ب) العدد (1). }
$$

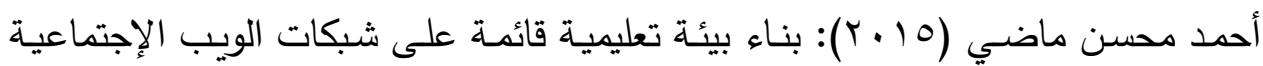

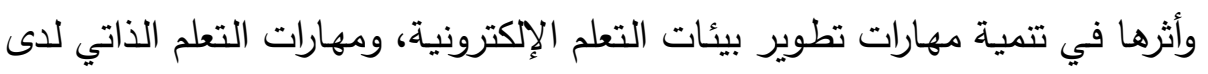
طلاب تكنولوجيا التعليم، رسالة ماجستير، كلية التربية النوعية، جامعة عين شمس.

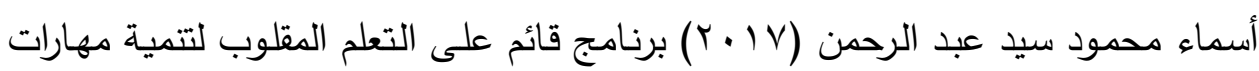
الثقافة المعلوماتية والتفكير الناقد للدى طـلاب الدراسـات العليا. رسالة ماجستير غير منشورة كلية التربية النوعية جامعة المنيا.

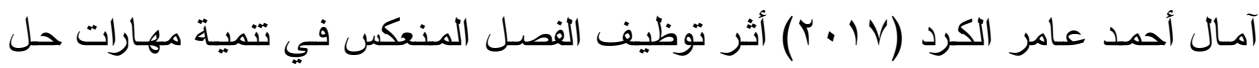
المسـائل الرياضـية والتواصـل الرياضـي لدى طالبـات الصفـ التاسـع الأساسـي بغزة. رسالة ماجستير غير منشورة، الجامعة الإسلامية، غزة.

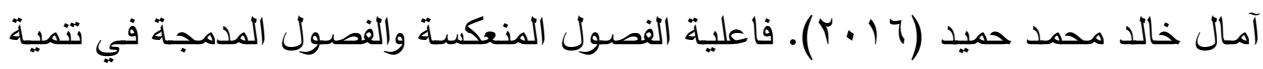
مهارات تصـيم صفحات الويـب التعليمية لطالبات كليـة التربية بالجامعـة الإسـلامية بغزة. رسالة ماجستير غير منشورة، كلية التربية، جامعة الإسلامية، عزة.

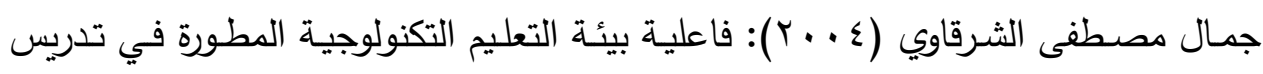
مقرر تكنولوجيا التعليم في تحصيل طلاب كلية التربية ومهاراتهم في استخدام هذه

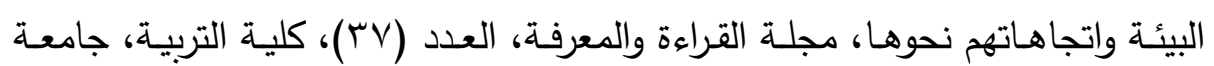
عين شمس. 
جميلة شريف محمد خالد (^ . . r) أثر استخدام بيئة تعلّم افتراضية في تعليم العلوم على تحصيل طلبة الصف السادس الأساسي في مدارس وكالة الغوث الدولية في محافظة نابلس. رسالة ماجستير منشورة، كلية الدراسات العليا، جامعة النجاح الوطنية، نابلس، فلسطين. جوناثان بيرجمان، وآرون سامز (ع ا • Y). التعلم المقلوب بوابة لمشاركة الطلاب: الكتاب المرافق للصف المقلوب. الرياض: مكتب التربية العربي لدول الخليج. حسن النجار ، سامح العجرمي (9 . . ب): مدى إمتلاك محاضري جامعة الأقصى لكفايات التعليم الإكتروني، مجلة جامعة القدس المفتوحة للأبحاث والدراسـات، العدد (7 ( )؛ جامعة القدس. حفصة جرادي، أحمد سويسي (9 ( ب ج) أهمية التعليم الرقمي في نقل المعرفة وتجويد أداء

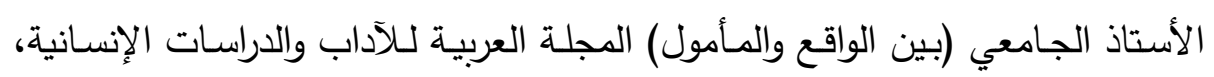

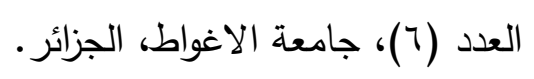

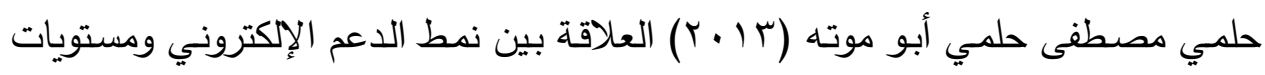
تقديمه عبر بيئات التعلم الافتراضية في تتمية التحصيل والتنكير الابتكاري، دراسات

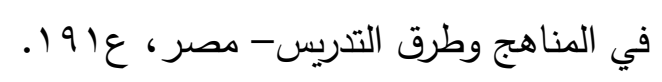

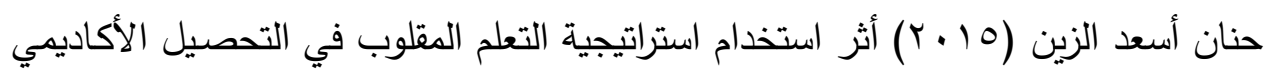

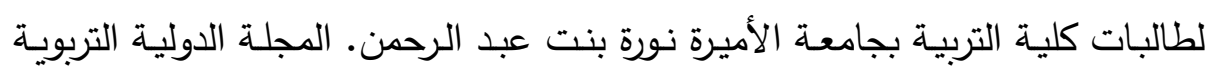

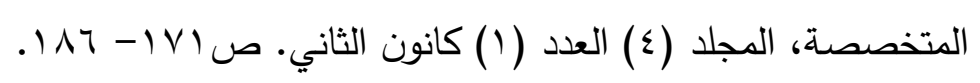

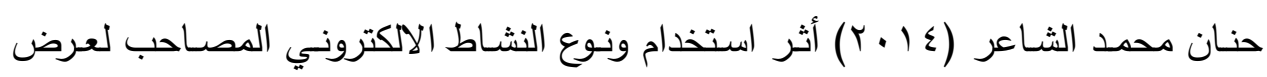
الفيديو في نموذج الفصل المقلوب على اكتسـاب المعرفة وتطبيقها وتفاعل المتعلم

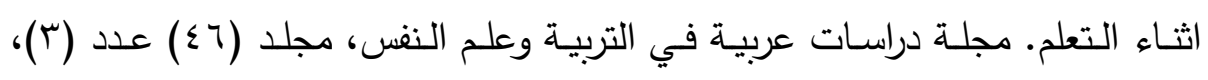
$.199-107$

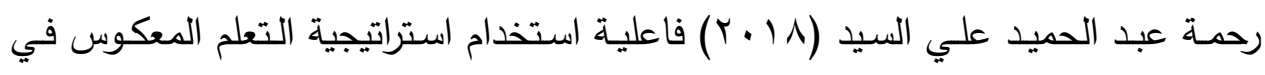
تمية مهارات توظيف المصـادر الرقمية في اللغـة العربية لدى تلاميذ الصف الثاني الإعدادي. رسالة ماجستير غير منشورة. كلية التربية، جامعة الزقازيق. 
عاطف أبو حميد الشرمان (10 ب r) التعلم المدمج والتعلم المعكوس. عمان: دار المسيرة. عبد العزيز طلبة (• ( • بأ): التعليم الإلكتروني ومستحدثات تكنولوجيا التعليم، المنصورة،

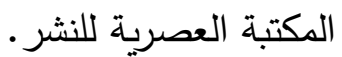

الغريب زاهـر إسـماعيل (1 . . r). تكنولوجيـا المعلومـات وتحديث التعليم. القـاهرة، عـالم

الغريب زاهر إسماعيل (9 . ㄷ): التعليم الإلكتروني من التطبيق إلى الاحتراف والجودة، القاهرة، عالم الكتب.

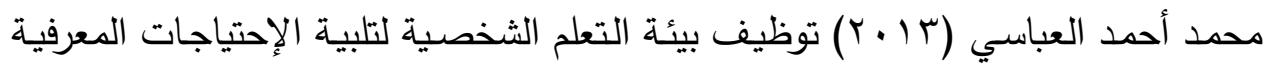
والمهارات البحثية لدى طلاب الدراسات العليا بكلية التربية واتجاهاتهم نحوها، رسالة دكتوراة، كلية التربية، جامعة المنصورة.

محمد سيف الدين بوفالطة، كريم زهيوة (9 ( ـ ب) واقع وافاق مشروع التعليم الرقمي بجامعة

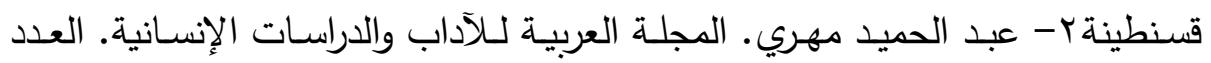

محمد عبد الكريم المـلاح ( • • ب): الأسس التربويـة لتقنيات التعليم الإلكتروني، عمـان، دار الثقافة.

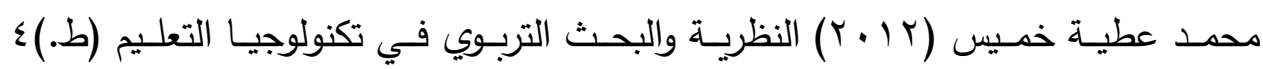
القاهرة: دار السحاب للطباعة والنشر والتوزيع.

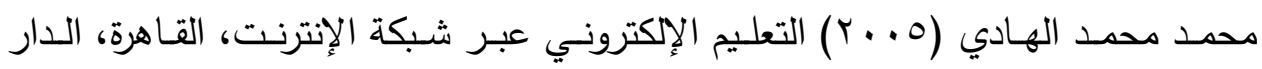
المصرية اللبنانية.

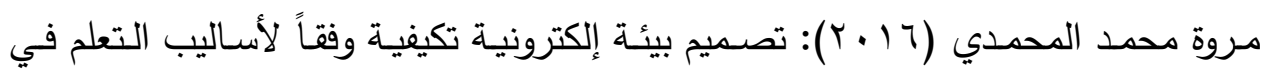

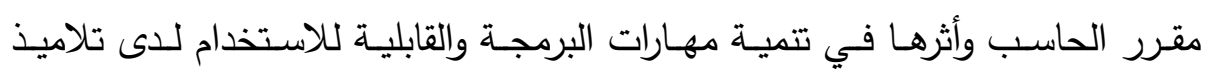
المرحلة الإعدادية، رسالة دكتوراة، كلية الدراسات العليا للتربية، جامعة القاهرة.

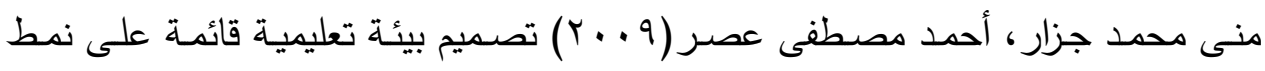
التدريب المـدمج لتتميـة مهـارات استخدام نظم إدارة بيئات التعليم الإلكترونيـة لـدى 
أعضاء هيئة التدريس ومعاونيهم .مجلة مستقبل التربية العربية. مصر : مجلد (7؟)

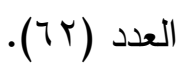

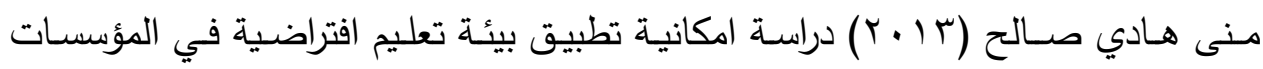
التعليميـة. مجلـة كليـة بغداد للعلوم الاقتصـادية الجامعـة. عدد خـاص بمؤتمر كليـة http://www.iasj.net/iasj التربية للبنات. جامعة بغداد. متاح على الموقع

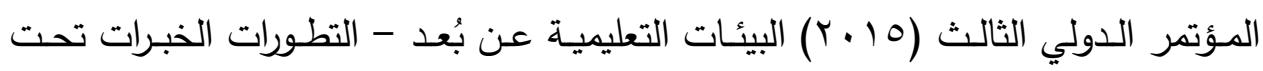

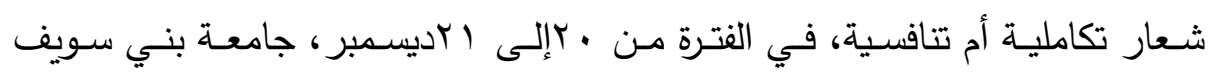
بالتعاون مع اتحاد الجامعات العربية.

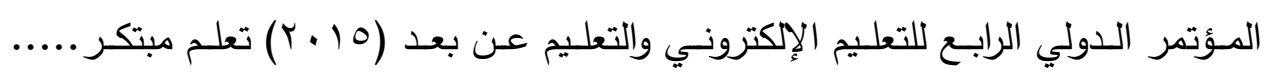

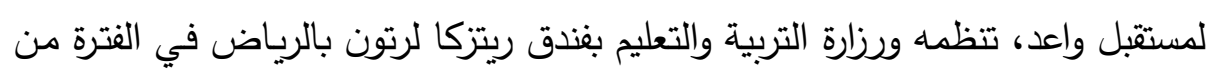

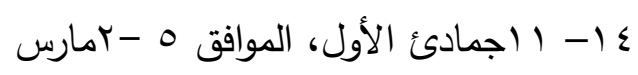

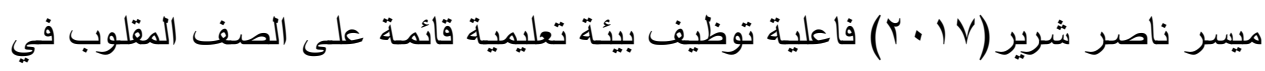

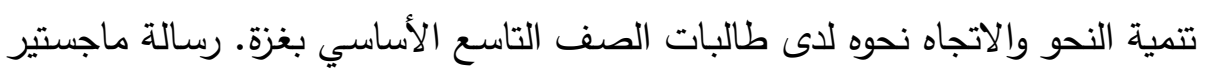
غير منشورة، كلية التربية، الجامعة الإسلامية، غزة.

نبيل جاد عزمي (^ . • ץ): تكنولوجيا التعليم الإلكتروني، القاهرة، دار الفكر العربي.

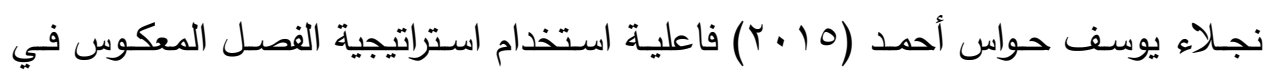

تتمية مهارات التفاعل الصفي لتدريس قواعد اللغة لطالبات الصف الثاني المتوسط.

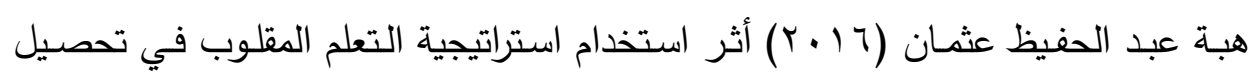
طالبات الصف السابع الأساسي في العلوم واتجاهاتهن نحو العلوم، رسالة ماجستير، كلية التربية، جامعة اليرموك، الأردن.

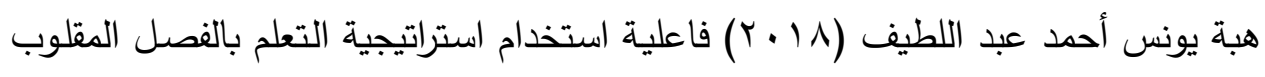

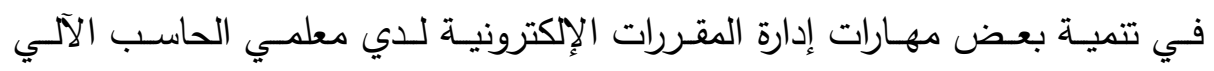

بالمرحلة الإعدادية. رسالة ماجستير غير منشورة كلية التربية النوعية جامعة طنطا. هناء عودة خضري (^ . . †) الأسس التربوية للتعليم الإكتروني، القاهرة، عالم الكتب.

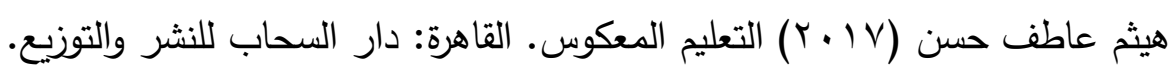


يحيى مصطفى عليان (Y ( + (Y): البيئة الإلكترونية، عمان، دار صنعاء للنشر والتوزيع.

Atkinson، L. Cole (2005): Schools as Learning Orghization: Relation Ships Between Professional Learning Communities and TechnologEnriched Learning Environments، PHD، The Univ. of Oklahoma.

Carter, R. \& Lange, M.(2005): Successful elearning strategies: interactive elearning for interactive age, entelisys technolog, Available at: http://www.elarninggguru.com/wpopers/

Emerging Trend in the Indian Higher Education System, International Journal on E-Learning, 1.(3), PP. 13-27.

Findlay Thompson, S., \& Mombourquette, P. (2014). Evaluation of a flipped classroom in an undergraduate business course. Business education \& Accreditation, 6(1), 63-71. Retrieved from.

Goodwin, B \& .Miller, K.(2013). Evidence on flipped classrooms is still coming in educational leadership, March 2013, 27-80.

Khirwadkar, A. Joshi, S.(2002): Knowledge Management through Elearning : An

Kristen Moran \& Amy Milsom (2015). The Flipped Classroom in Counselor Education, Counselor Education \& Supervision March, Volume 54.

O'Mahony, C., Higgs, B. \& Irwin, S. (2015). The media workshop: Designing a sustainable organization for a digital learning environment, https://dspace.mah.se/handle/2043/19736

Parker, M. A., \& Martin, F. (2010). Using virtual classrooms: Student perceptions of features and characteristics in an online and blended course. Journal of Online Learning and Teaching, 6(1), 135.

Parra . Julia . (2010). Amultiple-case study on the impact of teacher on face-lace classroom teaching practices. Ed. D.Pepperdine University . Doctoral Dissertation .

Sandy B.، Oleg L. (2000): A framework For Pedagogical Evaluation of Virtual Learning Environments، University of Wales-Bangor، pp 3-5، ERIC No.: ED 443494 